\title{
Recent Studies on Thermophilic Anaerobic Bioconversion of Lignocellulosic Biomass
}

\author{
Yu Xia, Herbert H.P. Fang, Tong Zhang*
}

\begin{abstract}
This paper reviews recent research developments in biological thermophilic lignocellulosic biomass conversion based on sixty four references published in the past 4 years (2009-2012). Bioconversion of hydrolysate and lignocellulosic biomass with or without pretreatment at thermophilic condition (with temperature higher than $50^{\circ} \mathrm{C}$ ) to fermentation product like hydrogen, methane, ethanol and carboxylic acids was discussed in terms of the bioaugmentation techniques and microorganisms involved. $\mathrm{pH}$ control by dosing buffering chemicals $\left(\mathrm{CaCO}_{3}\right.$ or $\left.\mathrm{KHCO}_{3}\right)$, co-culturing cellulolytic species (e.g. Clostridium) with fermentative species (e.g. Thermoanaerobacter or Thermoanaerobacterium) and co-digestion lignocellulosic biomass with nutrient sufficient feedstock like manure were the most popular bioaugmentation techniques in the studies reviewed. In addition, multi-fuel generation with bio-refinery methane production was testified to be more energy efficient than produce hydrogen or ethanol alone. This review may shed lights on the perspectives of scientific and technical challenges faced for the thermophilic anaerobic lignocellulose bioconversion.
\end{abstract}




\section{Table of contents}

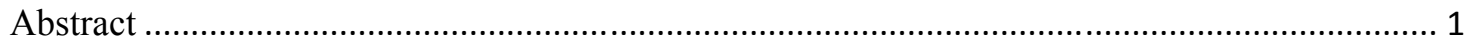

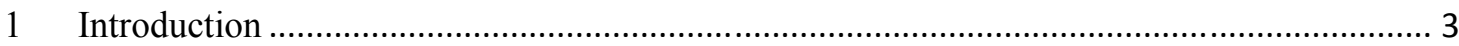

2 Fermentation of hydrolysate (liquid fraction after pretreatment) ......................................... 5

$2.1 \quad$ Tolerance to fermentation inhibitors .................................................................... 5

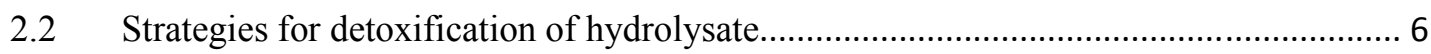

2.3 Strains used for hydrolysate fermentation ............................................................. 7

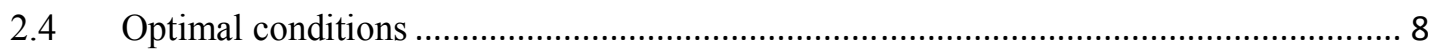

3 Fermentation of solid lignocellulosic biomass with/without pretreatment........................... 10

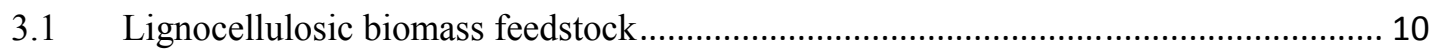

3.2 Affecting parameters of lignocellulosic biomass fermentation .................................. 10

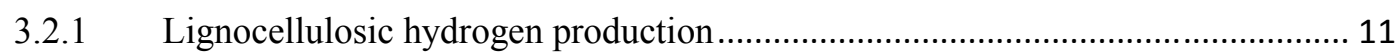

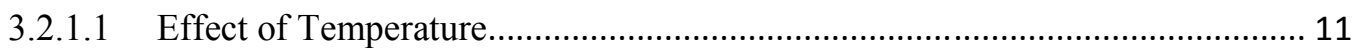

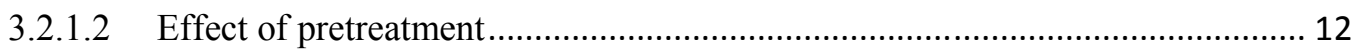

3.2.1.3 Effect of fermentation substrate …........................................................ 12

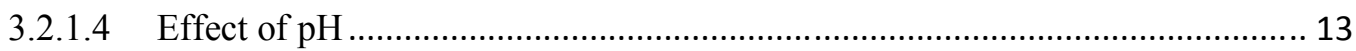

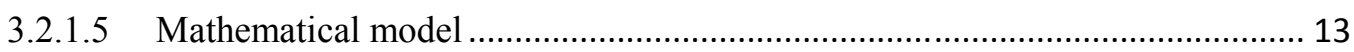

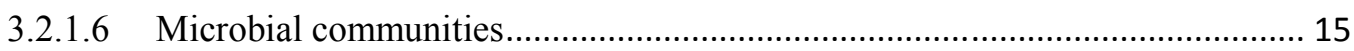

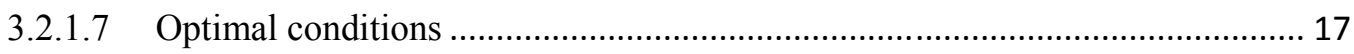

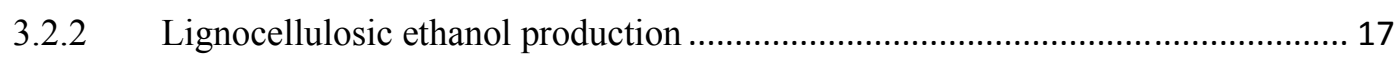

3.2.3 Lignocellulosic carboxylic acids production .................................................... 18

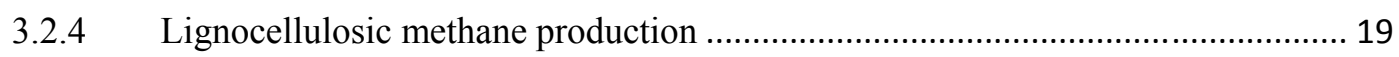

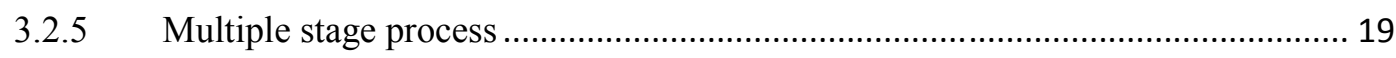

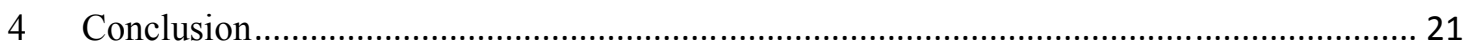

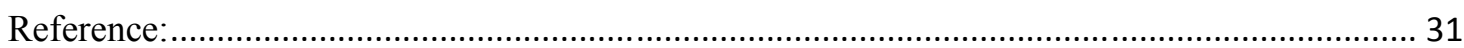




\section{Introduction}

Lignocellulosic biomass usually refers to plant biomass (agricultural and forestry), which generally consists of $30-56 \%$ cellulose, $10-27 \%$ hemicellulose and $3-30 \%$ lignin ${ }^{1}$. Lignocellulosic biomass is an ideal resource for biofuel production for its low cost and plentiful supply. A major doubt on using plant biomass as alternative energy source is how to convert it into biofuels (methanol, methane, hydrogen, etc.). Conversion of lignocellulosic biomass by microbial biochemical reactions has attracted worldwide attention as a potential low-cost green technology for renewable energy generation. Thermophiles or hyperthermophiles growing at elevated temperatures (generally from 50 to $85^{\circ} \mathrm{C}$ ) were especially attractive because the higher temperature is thermodynamically favorable for biofuel production ${ }^{2}$ and the contamination of unwanted microorganisms could be principally prevented ${ }^{3}$.

Among the recent studies on thermophilic lignocellulose bioconversion, most processes are designed to produce hydrogen for its high energy content and environmental friendly by-product of combustion. Biofuel in the liquid form, like ethanol ${ }^{4}$ and carboxylic acids, are also interested fermentation products for its prompt economic value as alternative and additive to fossil fuels or as chemical products. Additionally, many other studies also focus on converting lignocellulose into methane as it has superior feasibility in reactor scaling up and more complete carbon conversion of substrates.

Different from reviews focused solely on one type of fermentation product from biomass feedstock ${ }^{5-7,2,8,9}$, this article aims to give a comprehensively reviewed on the thermophilic bioconversion of lignocellulosic biomass. As the research focus varies largely between the liquid and solid form of feedstock applied, this review were divided into two branches according to the forms of substrates adopted: one branch targets the fermentation of liquid hydrolysate (liquid fraction generated from pretreatment of lignocellulosic biomass) while the other one summarizes the studies using raw or pretreated solid lignocellulosic biomass as feedstock. At this time, research is continuing on both branches of thermophilic fermentation, as none of them have been fully optimized. Thus, in this review, we summarize the latest scientific and technical tactics that were testified to promote thermophilic lignocellulosic biomass conversion in terms 
of substrate utilization, product yield as well as reactor stability. In addition, challenging issues of feedstock utilization and manipulation of microbial community was discussed to provide future perspectives of thermophilic lignocellulose bioconversion development. 


\section{Fermentation of hydrolysate (liquid fraction after pretreatment)}

Hydrolysate is ought to be a promising resource for fermentation as it contains high concentration of degradable sugars extracted from the lignocellulosic biomass during pretreatment, however besides releasing reduced oligosaccharides from cellulose and hemicellulose, the pretreatment process simultaneously generates less degradable pentose and strong fermentation inhibitors, both of which become the major challenges for the consequent hydrolysate fermentation.

\subsection{Tolerance to fermentation inhibitors}

The most common fermentation inhibitors include toxic compounds of furfural, hydroxymethylfurfural (HMF) and phenols as well as fermentation products like volatile fatty acids (VFAs), especially acetate. Toxic compounds of furfural, HMF and phenols generated from chemical or physical explosion of polysaccharides and lignin content of the biomass might inhibit the microorganisms, while VFAs produced from the pretreatment would induce product repression effect that impedes the initiation of fermentation reaction.

As a result, tolerance to such fermentation inhibitors, usually expressed as the maximum bearable hydrolysate concentration for stable biofuel production develops into one of the important standards to evaluate the fermentation performance. Among the studies reviewed, the common bearable concentration is around $30 \%(\mathrm{v} / \mathrm{v})$ of original hydrolysate solution. This means that hydrolysate must be diluted at least 3.3 times before applying to the anaerobic reactor, otherwise, overloading of hydrolysate will result in quick failure of the reactor indicated by lowered product yield, prolonged lag time as well as sudden $\mathrm{pH}$ drop ${ }^{10,11}$. Noticeably, there is only one study carried out by Kaparaju et al. ${ }^{12}$ which successfully utilized $100 \%$ hydrolysate in continuous stirring reactor (CSTR) for thermophilic methane production by applying hydrolysate derived from hydrothermal pretreatment of wheat straw which contained no furfural and HMF and very low concentration of phenols $\left(61 \mathrm{mg} \mathrm{L}^{-1}\right)$.

Chemical compositions of hydrolysate generated from various pretreatment processes were summarized in Table1. Although it is not within this paper's scope to review the relative merits of each pretreatment technology, the recalcitrance of hydrolysate, especially the content of fermentation inhibitors, depends greatly on the pretreatment 
process from which it derives. It is interesting to notice that studies used enzymatic hydrolysis after chemical pretreatment generally reported a less toxic hydrolysate composition with low or none furfural, HMF and phenols content. But no study had clearly demonstrated the detoxification effect of enzymatic hydrolysis on hydrolysate preparation. In addition, feedstocks with similar chemical composition could produce hydrolysate with totally different fermentability when pretreated at same conditions, for example Panagiotopoulos et al. observed a different fermentability of barley straw and corn stalk hydrolysate which is in strong contrast to the similarity of the composition of these two feedstocks (Table 4) ${ }^{13}$.

\subsection{Strategies for detoxification of hydrolysate}

In order to eliminate inhibitors in hydrolysate, Lee et al. (2011) demonstrated an effective approach to detoxify hardwood hydrolysate by dosing activated carbon at $2.5 \mathrm{wt} \%$ which selectively removed $42 \%$ of formic acid, $14 \%$ of acetic acid, $96 \%$ of HMF and $93 \%$ of the furfural with only $8.9 \%$ of sugars loss ${ }^{14}$.

In addition, reactor configuration was also proven to be an effective way to overcome the toxicity of hydrolysate. As demonstrated by Kaparaju et al. (2009) CSTR could achieve methane production of $297 \mathrm{~mL} \mathrm{CH}_{4} \mathrm{~g}^{-1} \mathrm{COD}$ with $100 \%$ (v/v) hydrolysate at organic loading rate (OLR) of $1.9 \mathrm{~g} \mathrm{COD} \mathrm{L}^{-1} \mathrm{~d}^{-1}$ while up-flow sludge blanket (UASB) even with diluted hydrolysate $(10 \%(\mathrm{v} / \mathrm{v}))$ and an higher OLR $\left(2.8 \mathrm{~g} \mathrm{COD} \mathrm{L}^{-1} \mathrm{~d}^{-1}\right)$ yielded less methane $\left(267 \mathrm{~mL} \mathrm{CH}_{4} \mathrm{~g}^{-1} \mathrm{COD}\right)^{12}$.

Longer hydrolytic retention time (HRT) is another practical method to lower the inhibitory content for fermentation. Both UASB and anaerobic filter reactor (AF) gave sharply decreased and subsequently fluctuated hydrogen production at an HRT of 0.5 day while the original rate and yield were recovered when the HRT was increased back to 1 day ${ }^{15}$. Nevertheless, too long HRT might result in cell mass washout, for example, hydrogenogens were washed out at an HRT of 2.5 days for a 1 -liter CSTR ${ }^{15}$. Hence, it is impractical to increase reactor tolerance to hydrolysate by solely prolonging HRT.

Co-digestion of toxic hydrolysate with nutrient-sufficient manure was used as an alternative approach to increase reactor's inhibitor tolerance capacity. Co-digestion of hydrolysate with pig manure $(1: 3 \mathrm{v} / \mathrm{v})$ promoted UASB tolerance from $10 \%$ to $25 \%$ 
hydrolysate, although methane yield of $219 \mathrm{~mL} \mathrm{CH}_{4} \mathrm{~g}^{-1} \mathrm{COD}$ was slightly lower than 267 $\mathrm{mL} \mathrm{CH}_{4} \mathrm{~g}^{-1} \mathrm{COD}$ without co-digestion ${ }^{12}$.

\subsection{Strains used for hydrolysate fermentation}

Most of the studies preferred using pure cultures for thermophilic anaerobic hydrolysate fermentation as shown in Table 2 and Table 3 which summarize the inoculum seed sources. Comparing to the mixed culture, pure culture inoculum, especially those genetically modified strains, is favorable for its higher product yield and production rate. However, the efficiency of pure culture systems is sensitive to environmental change ( $\mathrm{pH}$ and temperature variation) and very fragile to contamination by other microbial species. Fortunately, thermophilic condition provides an ideal environment for pure culture operation in which contamination is effectively prevented by the high temperature. For example, a reactor had been operated continuously for approximately 143 days, and no contamination was observed without using any agent to prevent bacterial contamination ${ }^{16}$.

Some strains have shown satisfactory tolerance to fermentation inhibitors in hydrolysate. Caldicellulosiruptor saccharolyticus DSM 8903 showed normal growth on hydrolysate of $\mathrm{NaOH}$ retreated biomass up to a sugar concentration of $20 \mathrm{~g} \mathrm{~L}^{-1}$ (corresponding to around $32 \%$ hydrolysate) ${ }^{17}$. Thermoanaerobacter BG1L1 exhibited significant resistance to high levels of acetic acid (up to $10 \mathrm{~g} \mathrm{~L}^{-1}$ ) and other metabolic inhibitors present in the hydrolysate ${ }^{16}$.

For the pure culture system used in hydrolysate fermentation, aside from the tolerance to inhibitors, the pentose (especially xylose) utilization capacity is another important parameter to evaluate the fermentation ability of the strain. As shown in Table1, the amount of xylose was equivalent to that of easily degradable glucose for most hydrolysate. The present of glucose in the substrate was reported to be adversary to the uptake of xylose by microorganisms. For instance, the presence of $50 \%$ glucose remarkably reduced the utilization rate of xylose from around $0.29 \mathrm{~g} \mathrm{~L}^{-1} \mathrm{~h}^{-1}$ to $0.09 \mathrm{~g} \mathrm{~L}^{-1}$ $\mathrm{h}^{-1}$ by Thermoanaerobacterium thermosaccharolyticum W16. The strain was able to produce hydrogen from xylose at $10.7 \mathrm{mmol} \mathrm{H}_{2} \mathrm{~L}^{-1} \mathrm{~h}^{-1}$ (yield of $2.19 \mathrm{~mol} \mathrm{H}_{2} \mathrm{~mol}^{-1}$ xylose) which was comparable to that from glucose of $12.9 \mathrm{mmol} \mathrm{H}_{2} \mathrm{~L}^{-1} \mathrm{~h}^{-1}$ (yield of $12.42 \mathrm{~mol} \mathrm{H}_{2} \mathrm{~mol}^{-1}$ glucose) ${ }^{18}$. 
Since some strains are glucose preferred, like Thermoanaerobacterium thermosaccharolyticum $\mathrm{W} 16^{18,19}$ and Thermotoga neapolitana ${ }^{20}$, while some others preferred xylose in the contrary, for example Caldicellulosiruptor saccharolyticus DSM $8903^{21,17,22}$, co-culture strategy has been used to promote xylose utilization. Co-culturing Caldicellulosiruptor saccharolyticus with the enriched compost microflora resulted in fast and simultaneous consumption of both glucose and xylose in the medium with a relatively high specific hydrogen production rate of $40 \mathrm{mmol} \mathrm{H}_{2} \mathrm{~g}^{-1}$ cell dry weight $\mathrm{h}^{-1}$ and high volumetric productivity of $2.5 \mathrm{mmol}-\mathrm{H}_{2} \mathrm{~L}^{-1} \mathrm{~h}^{-1} 21$.

\subsection{Optimal conditions}

The optimal operation conditions for thermophilic anaerobic hydrolysate fermentation are summarized in Table 2 and Table 3. On one hand, fermentative hydrogen yield from hydrolysate, on average around $9 \mathrm{mmol} \mathrm{H}_{2} \mathrm{~g}^{-1}$ sugar digested, is generally lower than the common hydrogen yield based on hexose fermentation of 11 $22 \mathrm{mmol} \mathrm{H}_{2} \mathrm{~g}^{-1}$ sugar digested (equivalent to $2-4 \mathrm{~mol}_{2} \mathrm{H}_{2}$ mol-hexose ${ }^{-1}$ ). This lowered yield is caused by the complex sugar composition and inhibitors in the hydrolysate as mentioned above. On the other hand, some studies showed great potential of thermophilic anaerobic hydrogen production from hydrolysate. It was reported the maximum hydrogen yield of $18.9 \mathrm{mmol} \mathrm{H}_{2} \mathrm{~g}^{-1}$ sugar digested (equivalent to $86 \%$ of theoretical hydrogen yield from hexose) in batch experiment using Caldicellulosiruptor saccharolyticus pure culture to digest Miscanthus hydrolysate $\left(10 \mathrm{~g}\right.$ sugar $\left.\mathrm{L}^{-1}\right){ }^{20}$. Furthermore, when fermenting the synthetic hydrolysate prepared using glucose and xylose at 1:1 ratio, co-culture of Caldicellulosiruptor saccharolyticus and compost microflora gave very high hydrogen yield of $21.1 \mathrm{mmol} \mathrm{H}_{2} \mathrm{~g}^{-1}$ sugar digested, which was $96 \%$ of theoretical hydrogen yield from hexose ${ }^{21}$. Zeidan and Van Niel's study had proven that with a proper detoxification process, high hydrogen yield could be obtained from thermophilic hydrolysate fermentation even the hydrolysate contained relatively high concentration of pentose like xylose (Table 1). In addition, pilot scale reactors (with volume of 1 liter or more) had been successfully set up for continuous hydrogen production from hydrolysate. The highest bearable ORL was $3.9 \mathrm{~g}$ sugar $\mathrm{L}^{-1} \mathrm{~d}^{-1}$ with $20 \%$ hydrolysate in UASB which produced hydrogen at $33.6 \mathrm{mmol} \mathrm{H}_{2} \mathrm{~L}^{-1} \mathrm{~d}^{-1}$ with yield of $8.8 \mathrm{mmol} \mathrm{H}_{2} \mathrm{~g}^{-1}$ sugar digested 15. Hydrolysate was also used as feedstock for thermophilic anaerobic methane and 
ethanol production as well. The highest methane yield of $16.8 \mathrm{mmol} \mathrm{CH}_{4} \mathrm{~g}^{-1} \mathrm{COD}$ digested was obtained in CSTR digesting $100 \%$ wheat straw hydrolysate ${ }^{12}$. Crespo et al. reported the highest ethanol yield of $0.46 \mathrm{~g}$ ethanol $\mathrm{g}^{-1}$ sugar digested using Caloramator boliviensi as inoculum to digest $20 \%$ sugarcane bagasse hydrolysate.

It is difficult to compare the product yield of thermophilic anaerobic fermentation among different studies as many of them did not contain information about the substrate utilization percentage which makes it impossible to put the yield number into the same unit. So the yield in this review is expressed in two different units, i.e. mmol product $\mathrm{g}^{-1}$ sugar digested and mmol product $\mathrm{g}^{-1}$ sugar added. The highest yield mentioned above is based on the unit of mmol product $\mathrm{g}^{-1}$ sugar digested which is more representative for the whole picture, yet it may not cover all the studies in the area. The major reason for lack of substrate utilization information maybe lie in the fact that the cost of lignocellulosic biomass feedstock is too low to arouse sufficient attention to how much is left-over when operating the reactor. In addition, the insoluble characteristics of lignocellulosic substrate also lead to inconveniency in quantification. However the information about feedstock utilization condition is very important to evaluate the process performance not only because it provides standardized yield quantification but also because adequate substrate conversion percentage is crucial to ensure the sustainability of reactors as leftover hydrolysate will bring about substrate inhibition of the microorganisms and uninterrupted accumulation of solid feedstock will cause mixing difficulty and physical clogging to the reactor. 


\section{Fermentation of solid lignocellulosic biomass with/without pretreatment}

\subsection{Lignocellulosic biomass feedstock}

Various types of lignocellulosic biomass have been used as feedstock for thermophilic fermentation studies. Their chemical compositions were summarized in Table 4. Among the various biomass resources, rice straw, wheat straw, and corn stover are considered as the most abundant and have the highest potential for biofuel production $^{23}$. Agricultural residues (straw, stalk and stover of farm crops) have relatively higher content of cellulose with less hemicellulose and lignin than forestry residues (wood stems) (Table 4). Aside from the sources of lignocellulosic materials from agricultural or forestry left-over, a list of potential bioenergy crops is being developed. Different from most plants assimilating $\mathrm{CO}_{2}$ first into $\mathrm{C} 3$ compound, energy crops like perennial grasses utilizing $\mathrm{CO}_{2}$ following the productive $\mathrm{C} 4$ photosynthesis pathway which was reported to have higher maximum efficiencies of light, nitrogen and water than $\mathrm{C} 3{ }^{24}$. Switchgrass, napiergrass and Miscanthus were the most common energy crops in the studied reviewed. Switchgrass is favored for its higher cellulose content which indicates a greater potential for fermentative biofuel production, nevertheless, napiergrass with higher hemicellulose and lower lignin content shows better accessibility for the pretreatment and hydrolysis process prior. One thing to be noticed is that in stark contrast to the long history of domestication of food crops to maximize productivity, until recently, minimal effort has been directed towards optimizing potential energy crops for the generation of biofuels ${ }^{24}$. In addition, purified cellulose such as microcrystalline cellulose ( $\alpha$-cellulose, Sigma-cellulose and Avicel), filter paper (with $>98 \%$ cellulose content) and Carboxymethyl Cellulose (CMC) were broadly utilized in the fermentation studies for the purpose of simplifying the system, or standardizing the product yield, or as a control.

\subsection{Affecting parameters of lignocellulosic biomass fermentation}

In this section, the anaerobic thermophilic lignocellulosic biomass fermentation is categorized according to the target fermentation products, namely hydrogen, methane, ethanol and carboxylic acids. Among the 41 reviewed research work on anaerobic thermophilic fermentation of solid lignocellulosic biomass, 16 studies were mainly focused on lignocellulosic hydrogen production while methane, ethanol and carboxylic acids production were respectively investigated in 6,6 and 4 studies. Another 6 studies 
investigated the multi-stage process combining two or three fermentation processes for biofuel production, while the rest 5 studied other aspects of fermentation other than yield of products.

\subsubsection{Lignocellulosic hydrogen production}

\subsubsection{Effect of Temperature}

Clearly, temperature is a crucial operational parameter because it largely determines the microbial community developing in the reactor. In the reviewed studies, the effect of thermophilic condition was often compared to mesophilic condition. Thermophilic condition with fermentation temperature above $50^{\circ} \mathrm{C}$ was in general reported to be beneficial for lignocellulosic hydrogen production because optimal temperature of hydrogenase for the reversible conversion of protons to molecular hydrogen was in the range from 50 to $70^{\circ} \mathrm{C}{ }^{25}$. Furthermore, higher cellulase activity (7.2 IU g g $^{-1}$ ungal pretreated cornstalk) was also observed under $55^{\circ} \mathrm{C}$ than $35^{\circ} \mathrm{C}{ }^{26}$. In addition, hydrogen production rates showed a significant $(\mathrm{P}<0.05)$ promotion at elevated fermentation temperature ${ }^{27}$.

As thermophilic biomass-degrading consortia are not as common as those mesophilic ones in nature, a general approach adopted requires certain steps of enrichment under the thermophilic condition. Hence, the temperature effect on such enrichment process was investigated extensively. Carver et al. (2002) found that enrichment at $60^{\circ} \mathrm{C}$ showed a shortened lag time and 10 folder higher $\mathrm{H}_{2}$ yield than enrichment conducted at $55^{\circ} \mathrm{C}$. Simultaneously, the methane formation, which is common in $55^{\circ} \mathrm{C}$, was eliminated after enriched at $60^{\circ} \mathrm{C} 27$. Enrichment at $60^{\circ} \mathrm{C}$ from rumen fluid also showed increased hydrogen production while enrichment at $52^{\circ} \mathrm{C}$ failed after 3 batches ${ }^{28}$. However, the enrichment of thermophilic compost in another study also conducted by Nissilä's group, following similar approach, showed just opposite result that all enrichments of the pretreated (at $80^{\circ} \mathrm{C}$ for $20 \mathrm{~min}$ ) compost community failed at $60^{\circ} \mathrm{C}$ while enrichment at $52^{\circ} \mathrm{C}$ showed the highest hydrogen yield ${ }^{29}$. Thus, there seems currently no standardized protocol to ensure successful enrichment of thermophilic cellulolytic consortia for lignocellulosic hydrogen production and the effectiveness of the enriched community was principally unable to control. 


\subsubsection{Effect of pretreatment}

Studies of the pretreatment process counted for a big proportion of lignocellulosic hydrogen researches. However, minimal effort had been put into optimizing pretreatment process for thermophilic fermentation. Among reviewed recent studies, only three of them involved the effect of pretreatment on thermophilic lignocellulosic hydrogen production. A pretreatment method combining 10\% ammonia and $1.0 \%$ dilute sulfuric acid was reported to be able to increase digestibility of rice straw by hyperthermophile Thermotoga neapolitana from $29 \%$ to $85.4 \%$ with improved hydrogen yield from 2.3 to $2.7 \mathrm{mmol} \mathrm{H}_{2} \mathrm{~g}^{-1}$ straw ${ }^{30}$. A so-called Microwave-assisted acid pretreatment (MAP) showed obvious advantages of short duration and high efficiency of lignocellulosic hydrolysis as demonstrated by the smaller particle size and larger specific surface area of treated corn stover. ${ }^{31}$ Likely lime pretreatment was also testified to promote thermophilic hydrogen yield from cornstalk by $38.1 \%{ }^{32}$.

\subsubsection{Effect of fermentation substrate}

Thermophilic cellulosic hydrogen production was affected by the type and amount of substrate applied in the fermentation. Among sweet sorghum, sugarcane bagasse, wheat straw, maize leaves and silphium, wheat straw was reported as the best substrate for Caldicellulosiruptor saccharolyticus in terms of $\mathrm{H}_{2}$ production capacity. The strain was able to produce hydrogen from wheat straw at $44.7 \mathrm{~L} \mathrm{H}_{2} \mathrm{~kg}^{-1}$ dry biomass and $\mathrm{H}_{2}$ yield of $3.8 \mathrm{~mol} \mathrm{H}^{2} \mathrm{~mol}^{-1}$ glucose ${ }^{33,13}$. One the other hand, co-digestion of cellulose with microalgal biomass like Dunaliella tertiolecta or Chlorella vulgaris would increase cellulosic hydrogen yield. Higher yield of $7.7 \mathrm{mmol} \mathrm{H}_{2} \mathrm{~g}^{-1}$ volatile solids (VS) was obtained when cellulose was co-digested with D. tertiolecta ${ }^{34}$. Interestingly, cosubstrate of yeast extract exhibited a significant stimulation of cellulose degradation and hydrogen production from filter paper that the extent of cellulose utilization and hydrogen production by co-culture of Clostridium thermocellumand and Clostridium thermopalmarium displayed a linear relationship with the logarithm of the yeast extract concentration, and the optimal weight ratio of yeast extract to cellulose was $1: 1^{35}$.

Substrate loading also influenced the hydrogen production. Chen et al. (2012) reported that increasing substrate loading from 30 to $90 \mathrm{~g} \mathrm{TS} \mathrm{L}^{-1}$ improved hydrogen yield but further to $120 \mathrm{~g} \mathrm{TS} \mathrm{L}^{-1}$ resulted in decreased hydrogen yield ${ }^{36}$. Meanwhile, 
although Clostridium thermocellum grew 22\% slower at low-cellulose concentrations (with growth rate of $0.15 \mathrm{~h}^{-1}$ ) than at high-cellulose concentrations, the maximum specific rate of $\mathrm{H}_{2}$ production $\left(6.41 \pm 0.13 \mathrm{mmol} \mathrm{H}_{2} \mathrm{~g}^{-1}\right.$ dry cell $\left.\mathrm{h}^{-1}\right)$ obtained during the exponential phase from low-carbon cultures was about 37\% higher than that obtained from high-carbon cultures ${ }^{37}$.

\subsubsection{Effect of pH}

$\mathrm{pH}$ is one of the well-known affecting factors of fermentation process. Acidic condition was observed to be adverse to thermophilic cellulosic hydrogen production. Chen et al. (2012) found that $\mathrm{pH}<6.0$ was unsuitable for thermophilic cellulose hydrolyzing microorganisms and no hydrogen was generated with initial $\mathrm{pH}$ lower than 5.5. Similarly, Xia et al. (2012) reported pH lower than $\mathrm{pH} 6.0$ would induce the grow of Thermoanaerobacterium over the more cellulolytic Clostridium species and thus resulted in process failure of the semi-batch reactor. Optimal initial $\mathrm{pH}$ was reported to be $\mathrm{pH} 6.5$ with hydrogen yield of $1.01 \mathrm{mmol} \mathrm{H}_{2} \mathrm{~g}^{-1} \mathrm{TS}$ added for heat pretreated sludge inoculums ${ }^{36}$ (Table 5). Slightly higher optimal $\mathrm{pH}$ of $\mathrm{pH} 7.3$ was reported for enriched rumen fluid ${ }^{28}$. Likewise, increase buffering capacity of the reaction medium was proven to be favorable to maintain efficient cellulose degradation especially at high cellulosic substrate loading, for example, at a load of filter paper of $9 \mathrm{~g} \mathrm{~L}^{-1}$, increasing the alkali $\mathrm{KHCO}_{3}$ concentration from 0 to $60 \mathrm{mM}$ promoted cellulose utilization by 7 times from $1.23 \mathrm{~g} \mathrm{~L}^{-1}$ (equivalent to $13.5 \%$ substrate conversion) to $8.59 \mathrm{~g} \mathrm{~L}^{-1}$ (equivalent to $94.3 \%$ substrate conversion) ${ }^{35}$.

\subsubsection{Mathematical model}

Attempt had been made to use mathematical model to predict thermophilic lignocellulosic hydrogen yield and evaluate influence of operational parameters. Both thermodynamic equation and continuum particle distribution model (CPDM) was applied to predict hydrogen yield.

\subsection{Model based on thermodynamic equation}

Based on acids and hydrogen yield in the batch experiment, Forrest et al. (2011) use thermodynamic formula Eq. (1) and (2) to calculate the theoretical energy selectivity $(\gamma$, $\mathrm{kJ} / \mathrm{g}$ ) of the reaction in batch test and then applying the result to predict hydrogen yield 
using formula Eq. (3) in continuous MixAlco ${ }^{\mathrm{TM}}$ process which shared similar fermentation conditions, including substrate, buffer and incubation temperature, with batch tests.

$$
\begin{gathered}
\Delta G_{c}=\sum_{j} A_{c i d} \times\left[\sum_{i}\left(x_{i} \times \Delta G_{j i}\right)\right]+\mathrm{H}_{2} \times \Delta G_{\mathrm{H}_{2}} \\
\gamma \equiv \frac{\Delta G_{c}}{\Delta V S} \\
\mathrm{H}_{2}(\mathrm{~mol})=\frac{\gamma \times(\Delta \mathrm{VS})-\sum_{\mathrm{j}} \mathrm{Acid}_{\mathrm{j}} \times\left[\sum_{\mathrm{i}}\left(\chi_{\mathrm{i}} \times \Delta \mathrm{G}_{\mathrm{ji}}\right)\right]}{\Delta \mathrm{G}_{\mathrm{H}_{2}}}
\end{gathered}
$$

$\Delta G_{c}:$ the total Gibbs free energy change from catabolic reactions $(\mathrm{kJ})$

Acid $_{i}$ : the carboxylic acid of Type $j(\mathrm{~mol})$

$x_{i}$ : the mol fraction of sugar of Type $i$ (e.g., mol hexose/mol total sugars)

$\Delta G_{j i}:$ the Gibbs free energy of reaction for Type $j$ acid from Type $i$ sugar $(\mathrm{kJ} / \mathrm{mol})$

$\Delta G_{\mathrm{H}_{2}}:$ the Gibbs free energy of reaction for hydrogen $(\mathrm{kJ} / \mathrm{mol})$

$\gamma:$ the energy selectivity of a system (kJ/g VS digested)

$\Delta V S:$ amount of VS digested $(\mathrm{g})$

The above thermodynamic calculation was able to predict hydrogen production from paper fermentation to within $11 \%$ and from bagasse fermentation to within $21 \%$ of the actual production by an enriched mixed thermophilic cellulolytic culture ${ }^{38}$.

\subsection{CPDM}

In addition, the concept of continuum particles was used in the continuum particle distribution model (CPDM) to describe the thermophilic lignocellulosic acids production. A "continuum particle" is defined as $1 \mathrm{~g}$ of initial volatile solids with a composition identical to the biomass being fed to the fermentor. Eq. (4) is the governing equation deployed in the CPDM method. It relates the specific reaction rate $\left(\hat{r}_{\text {pred }}\right)$ with acetic acid equivalent concentration (Aceq) and substrate conversion (x). The detailed description and implementation of the CPDM model could be found in ${ }^{39}$. 


$$
\begin{aligned}
\hat{r}_{\text {pred }}=\frac{e(1-x)^{f}}{1+g(\varphi \cdot \text { Aceq })^{h}} & \\
\text { Aceq }(g / L) & =60.05 \times[\alpha(\mathrm{mol} / \mathrm{L})] \\
\alpha(\mathrm{mol} / \mathrm{L})= & \operatorname{acetic}(\mathrm{mol} / \mathrm{L}) \\
& +1.75 \times \text { propionic }(\mathrm{mol} / \mathrm{L}) \\
& +2.5 \times \text { butyric }(\mathrm{mol} / \mathrm{L}) \\
& +3.25 \times \text { valeric }(\mathrm{mol} / \mathrm{L}) \\
& +4.0 \times \text { caprioc }(\mathrm{mol} / \mathrm{L}) \\
& +4.75 \times \text { heptanoic }(\mathrm{mol} / \mathrm{L})
\end{aligned}
$$

$\hat{r}_{\text {pred }}:$ the reaction rate per continuum particle

$x:$ fraction of conversion of Volatile Solids (VS)

$e, f, g, h:$ empirical constants which need to be determined by the least square method in batch test.

$\varphi$ : the ratio of total grams of carboxylic acids to total grams of acetate; it is introduced to avoid inhibitory effect of higher acids that would overestimate the specific rate

Aceq: mass total acids concentration in term of acetic acids mass equivalent on a mass basis

$\alpha$ : molar total acids concentration in terms of acetic acids molar equivalent on a mass basis

The CPDM was reported to be able to predict substrate conversion and total acid production with averagely around $10 \%$ error in semi-continuous batch reactors and the MixAlco process ${ }^{39,40}$. In addition, CPDM optimizations show that high conversion ( $>$ $80 \%$ ) and total acid concentration of $21.3 \mathrm{~g} \mathrm{~L}^{-1}$ were possible with $300 \mathrm{~g}$ substrate $\mathrm{L}^{-1}, 30$ days liquid residence time, and $3 \mathrm{~g} \mathrm{~L}^{-1}$ day $^{-1}$ solid loading rate ${ }^{39}$.

\subsubsection{Microbial communities}

Nowadays, great research interest are devoted into seeking answers to the crucial microbiologic questions of "who is doing what" and "how to control them" in various 
functional microbial communities. Without exception, communities involved in thermophilic lignocellulosic hydrogen production were extensively studied from characterization of community structure of mixed fermentation consortia to optimization of isolated strains. A co-culture of hydrolytic and fermentative bacteria seems crucial for many lignocellulose degrading systems. Chen et al. (2012) observed an association of hydrolytic bacteria Clostridium pasteurianum and Clostridium stercorarium with fermentative bacteria of Thermoanaerobacterium saccharolyticum in the repeated-batch reactor inoculated with sludge from municipal wastewater treatment plant. This association led to the microbial hydrolysis and fermentation of raw rice straw avoiding the pretreatment step $^{36}$. Similar community was enriched from compost pile as revealed by pyrosequencing analysis that the enriched TC60 consortium (11 OTUs) was predominated by Thermoanaerobacter (49\%), Clostridium spp.(30\%) and Clostridium thermocellum (21\%) ${ }^{27}$. Again enrichment from compost pile by Nissilä et al. (2011) also showed that a bacterium closely related to Thermoanaerobium thermosaccharolyticum was mainly responsible for hydrogen production and bacteria closely related to Clostridium cellulosi and Clostridium stercorarium were responsible for cellulose degradation ${ }^{29}$. Slightly different from compost and sludge source, enrichment of rumen fluid showed a sole dominance of Clostridium stercorarium subsp. Leptospartum ${ }^{28}$. Briefly, no matter what source inoculation applied, the superior ability of genus Clostridium in thermophilic biomass degradation was well demonstrated by its dominance in the enriched thermophilic cellulolytic cultures. And the microbial coexistence of fermentative Thermoanaerobacterium or Thermoanaerobacter with cellulolytic Clostridium indicated a positive function of microbial co-culture on thermophilic lignocellulosic hydrogen production.

Such effect of co-culturing hydrolytic and fermentative strain was further investigated with isolated strains. For example, Li and Liu (2012) reached 94.1\% higher hydrogen yield of $68.2 \mathrm{~mL} \mathrm{H}_{2} \mathrm{~g}^{-1}$ cornstalk with co-culture of Clostridium thermocellum and Clostridium thermosaccharolyticum ${ }^{41}$. And the volumetric hydrogen production was promoted by 2.4 times as compared to mono-culture by the co-cultivation of fermentative Clostridium thermopalmarium with cellulolytic Clostridium thermocellumand at ratio $0.05: 1^{35}$. In addition, it is interesting to notice that strains of 
genus Thermoanaerobacterium though had been found to co-exist with cellulolytic Clostridium in several enriched thermophilic consortia, was seldom used in co-culture study on solid lignocellulose fermentation, in spite quite many hydrolysate studies use it.

\subsubsection{Optimal conditions}

The optimal conditions for anaerobic thermophilic lignocellulosic hydrogen production were summarized in Table 5. Again the discrepancy of yield calculation, make it difficult to compare fermentation performance among literatures. However, general trend of hydrogen yield could still be observed that the simplified fermentation environment tended to have higher hydrogen production yield than those of real reactor system. Simplification either by inoculating pure culture or using purified cellulosic substrate like $\alpha$-cellulose or filter paper resulted in higher hydrogen yield with the highest yield of $21.1 \mathrm{mmol} \mathrm{H}_{2} \mathrm{~g}^{-1}$ glucose equivalent digested obtained by applying Caldicellulosiruptor saccharolyticus. DSM8903 to ferment wheat straw ${ }^{33}$. In reactors treating complex lignocellulosic substrate, the highest reported hydrogen yield was 8.5 mmol $\mathrm{H}_{2} \mathrm{~g}^{-1}$ glucose equivalent digested when digesting pretreated corn stover ${ }^{31}$. Additionally, higher hydrogen yield may be achieved by enlarging reactor size, for example, hydrogen yield in the 8-liter CSTR reached $74.9 \mathrm{~mL} \mathrm{H}_{2} \mathrm{~g}^{-1}$ cornstalk which was $9.8 \%$ higher than that in the $125 \mathrm{~mL}$ anaerobic bottle ${ }^{41}$. Similar hydrogen yield increase was also demonstrated in 100-liter CSTR as compared to $125 \mathrm{~mL}$ batch test ${ }^{42}$. The most likely reason for such phenomenon is that the larger reactor tends to have better mixing and mass transfer which will promote both the hydrolysis and hydrogen generation reaction.

\subsubsection{Lignocellulosic ethanol production}

The approach of co-culturing was wildly used in the studies of lignocellulosic ethanol production. Strains from genus of Clostridium and Thermoanaerobecter were most often used in this approach. Ethanol production by co-culture of Clostridium themocellum and Clostridium thermolacticum was up to 2-fold higher than mono-culture of each strain, especially with microcrystalline cellulose as substrate ${ }^{43}$. Similarly coculture Thermoanaerobacter strain X514 with Clostridium thermocellum promoted the ethanol production by $440 \%{ }^{44}$. 
Genetic modification of ethanol-producing strain is another effective way to promote ethanol yield. By deleting the genes for both lactate dehydrogenase (Ldh) and phosphotransacetylase (Pta), the stable strain evolved after 2,000h showed 4.2-fold increase in ethanol yield over the wild-type strain ${ }^{45}$. In addition, Yao and Mikkelsen (2010) had successfully modified the metabolism of Thermoanaerobacter mathranii towards enhanced ethanol generation by eliminating the $I d h$ gene and expressing a heterologeous gene gld $^{46}$.

Several other interesting observations on lignocellulosic ethanol production were reported in literature. It was reported by $\mathrm{Xu}$ and Tschirner (2011) that higher initial ethanol level favored the ethanol production for both mono-culture and co-culture of Clostridium themocellum and Clostridium thermolacticum. At the optimized condition, the ethanol production from microcrystalline cellulose increased from $1.0 \mathrm{~g} \mathrm{~L}^{-1}$ at an initial ethanol level of $0 \mathrm{~g} \mathrm{~L}^{-1}$ to $3.8 \mathrm{~g} \mathrm{~L}^{-1}$ at an initial ethanol level of $4 \mathrm{~g} \mathrm{~L}^{-1} 43$. Unexpectedly, acetate also showed an stimulatory effect on ethanolic fermentation by Thermoanaerobacter ethanolicus 39E, enhancing ethanol production by up to $394 \%$ whereas lactate was in general inhibitory to ethanolic fermentation ${ }^{47}$. In addition, the presence of a complete vitamin B12 biosynthesis pathway in Thermoanaerobacter strain X514 was testified to be associated with the higher ethanolic fermentation efficiency as compared to another strain 39E in which the B12 biosynthesis pathway was incomplete. The significance of the vitamin B12 bio-synthesis capacity was further supported by the observation of improved ethanol production in strain 39E (by 203\%) following the addition of exogenous vitamin B12 ${ }^{44}$.

\subsubsection{Lignocellulosic carboxylic acids production}

Carboxylic acids like acetic acid are another type of targeting products for lignocellulosic fermentation because it could be chemically converted into a wide variety of chemicals and fuels. Increase fermentation temperature from $40^{\circ} \mathrm{C}$ to $55^{\circ} \mathrm{C}$ resulted in higher total acids yield but lower substrate conversion ratio ${ }^{48,49}$. In addition, the continuum particle distribution model (CPDM) was reported to be able to predict substrate conversion and total acid production with averagely around $10 \%$ error in semicontinuous batch reactor and the MixAlco process ${ }^{39,40}$. Another interesting phenomenon found by Budhavaram and Fan (2009) was that the buffering of $\mathrm{CaCO}_{3}$ which could result 
in $10 \mathrm{~g} \mathrm{~L}^{-1}$ more lactic acid production in LB medium was ineffective when a so-called "lean" solution with limited phosphate and nutrient was used as the fermentation medium 48. However the authors failed to provide any tentative explanation of the observed negative effect of $\mathrm{pH}$ control.

\subsubsection{Lignocellulosic methane production}

Stable cellulose-utilizing thermophilic methanogenic community had been enriched from several sources including compost, digestion sludge, soil and so forth ${ }^{50-52}$. Coexistence of thermophilic cellulose degrader with methanogens had been commonly observed in these communities. The most common thermophilic cellulose degraders reported were affiliated to the genus of Clostridium. The importance of Clostridium species in the lignocellulosic methane production had been validated in two studies in both of which the sudden drop of Clostridium proportion in the community either induced by $\mathrm{pH}$ drop or by substrate alteration resulted in significant performance declination of the reactor ${ }^{50,53}$. Additionally, co-digestion of lignocellulosic waste with nitrogen-rich waste like palm oil mill effluent (POME) ${ }^{52}$ could effectively improve the methane yield, for example, methane yield of 276-340 $\mathrm{mL} \mathrm{CH}_{4} \mathrm{~g}^{-1}$ VS-added from codigesting palm empty fruit bunches with POME was 25-32\% higher than that from digesting fruit bunches alone.

\subsubsection{Multiple stage process}

Besides the one-stage fermentation studies mentioned above, fermentation pipeline in which the effluent or residues of the first stage was further fermented in subsequent reactors was developed to improve the overall energy efficiency. Such multiple-stage strategy contains more than one fermentation process carried out in separated reactors. From the perspective of biorefinery, a final stage of bio-methane production was usually adopted to refine the effluent or residues of the biohydrogen or bioethanol production. A roughly $30 \%$ more energy recovery could be added up to overall process by the refinery stage of bio-methane generation ${ }^{54-58}$. In addition, multiple-stage process enabling the production of multiple biofuels could benefit the subsequent utilization of the fuels, for example, addition of a small amount of hydrogen to methane would significantly improve the efficiency and stability of combustion in motors because hydrogen has eight times faster flame speed than methane and the addition of hydrogen serves to reduce 
air/fuel ratio (lambda) as well. However, directly fermenting pretreated wheat straw into bio-methane showed higher energy output (10452 $\mathrm{MJ} \mathrm{Ton}^{-1}$ of dry matter) than firstly fermenting into ethanol or hydrogen (around $8000 \mathrm{MJ} \mathrm{ton}^{-1}$ of dry matter). Furthermore combustion of the straw had the highest energy output of around $1600 \mathrm{MJ} \mathrm{ton}^{-1}$ of dry matter ${ }^{59}$. Despite low energy output from production of biofuels as compared to incineration of lignocellulosic biomass, the advantage of mitigating world-wide fossil fuel shortage by generating liquid fuel alternatives and negligible environmental damage of the fermentation process serves to explain the importance of conversion of biomass to biofuels. Finally, by comparing different technological scenarios, Dias et al. claimed that integrating first and second generation ethanol production technique leaded to better economic results for bioethanol plant, especially when advanced hydrolysis technologies and pentoses fermentation were included ${ }^{60}$. 


\section{Conclusion}

Thermophilic fermentation process although be regarded as a promising technology to promote lignocellulose hydrolysis and fermentation efficiency, is still at its infantile stage with a number of aspects requiring systematic evaluation and optimization. Based on reviews of the recent studies on the thermophilic anaerobic lignocellulose bioconversion, major knowledge gaps include:

First, complete lignocellulosic substrate conversion is still practically impossible no matter utilizing hydrolysate or after-pretreated solid residues, except for reactors with simplified systems or purified substrates. Even though the adversity of the unutilized substrate to the overall fermentation process had been observed in many scenarios, the reason for such reaction cease was rarely addressed or paid attention to in most studies.

Second, information of microbial community structure is still quite limited and rather static. Little quantitative microbial characterization of the fermentative communities could be provided to facilitate the essential stages of reactor operation such as reactor start-up, failure recovery etc. The introduction of the emerging Next Generation Sequencing (NGS) technology into the dynamic monitoring of reactor communities would help setting up the knowledge linkage between variation of microbial structure and reactor performance.

Last but not the least, standardized performance evaluation measure is needed. The expression of product yield is inconsistent among studies, which causes difficulty to the systematic comparison of fermentation performance among studies. In some cases, the product yield was simply expressed in the unit of product per mass of substrate added while in other cases it was defined as product per mass of substrate converted. Given the lignocellulosic substrate was not fully converted in most of the case; these two units were hardly consistent and impossible to compare.

Based on the above review, it is clear that converting lignocellulose into biofuels at thermophilic condition is a very feasible solution to produce biofuels from lignocellulosic materials. While, concern remains on how to establish an applicable and affordable thermophilic lignocellulose conversion process. $\mathrm{pH}$ control by dosing buffering 
chemicals $\left(\mathrm{CaCO}_{3}\right.$ or $\left.\mathrm{KHCO}_{3}\right)$, co-culturing cellulolytic species (e.g. Clostridium) with fermentative species (e.g. Thermoanaerobacter or Thermoanaerobacterium) and codigesting lignocellulosic biomass with nutrient sufficient feedstock like manure were the most applicable bioaugmentation strategies in the studies reviewed. Another considerable pathway is to develop a multiple-stage process for multi-fuel output like ethanol- $\mathrm{CH}_{4}$ or $\mathrm{H}_{2}-\mathrm{CH}_{4}$ from raw lignocellulosic waste. Aside from the scientific research, a throughout economic assessment is also essential in order to put this entire blueprint into reality. 
Table 1 Chemical composition hydrolysate derived from various pretreatment and hydrolysis technologies.

\begin{tabular}{|c|c|c|c|c|c|c|c|c|c|c|c|c|c|}
\hline $\begin{array}{c}\text { Source } \\
\text { biomass }\end{array}$ & $\begin{array}{l}\text { Pretreatment and } \\
\text { hydrolysis }\end{array}$ & TS \% & VS\% & $\begin{array}{l}\text { Furfural } \\
\left(\mathrm{mg} \mathrm{L}^{-1}\right)\end{array}$ & $\underset{\left(\mathrm{mg} \mathrm{L}^{-1}\right)}{\mathrm{HMF}}$ & $\begin{array}{l}\text { Phenols } \\
\left(\mathrm{mg} \mathrm{L}^{-1}\right)\end{array}$ & $\begin{array}{l}\text { Total } \\
\text { sugars } \\
\left(\mathrm{g} \mathrm{L}^{-1}\right)\end{array}$ & $\begin{array}{l}\text { Glucose } \\
\left(\mathrm{g} \mathrm{L}^{-1}\right)\end{array}$ & $\begin{array}{l}\text { Xylose } \\
\left(\mathrm{g} \mathrm{L}^{-1}\right)\end{array}$ & $\begin{array}{l}\text { Arabinose } \\
\left(\mathrm{g} \mathrm{L}^{-1}\right)\end{array}$ & $\begin{array}{l}\text { VFA } \\
\left(g^{-1}\right)\end{array}$ & $\begin{array}{l}\text { Others } \\
\left(\mathrm{g} \mathrm{L}^{-1}\right)\end{array}$ & Reference \\
\hline $\begin{array}{c}\text { Sugarcane } \\
\text { bagasse }\end{array}$ & Steam explosion & - & - & 500 & 100 & - & 25.2 & 1.5 & 22.2 & - & 4.1 & $\begin{array}{c}1.5 \\
\text { cellobiose } \\
\end{array}$ & 61 \\
\hline Wheat straw & $\begin{array}{c}\text { Hydrothermal } \\
\text { pretreatment }\end{array}$ & 4.4 & 3.3 & 250 & 140 & 140 & 15.5 & 2.9 & 11.3 & 1.3 & 0.7 & - & 11 \\
\hline Wheat straw & $\begin{array}{c}\text { Hydrothermal } \\
\text { pretreatment }\end{array}$ & 12.0 & 10.2 & N.D. & N.D. & 61 & 84.5 & 10.3 & 6.9 & N.D. & 0.18 & 75.6 lignin & 10 \\
\hline Hardwood chip & Autohydrolysis & - & - & 780 & 130 & N.D. & 3.62 & 0.36 & 1.96 & 0.68 & 10.36 & - & 14 \\
\hline Corn stover & Acid pretreatment & - & - & 410 & - & 40 & 11.84 & 1.85 & 9.11 & 0.88 & 1.35 & - & 19 \\
\hline Corn stover & $\begin{array}{l}\text { Dilute acid } \\
\text { pretreatment }\end{array}$ & 30 & - & 3800 & 600 & - & 83.1 & 15.6 & 67.5 & - & 13.7 & - & 62 \\
\hline Corn stover & $\begin{array}{l}\text { Acid pretreatment and } \\
\text { enzyme hydrolysis }\end{array}$ & - & - & - & - & - & 31.5 & 17.3 & 12.6 & 1.9 & - & - & 18 \\
\hline $\begin{array}{l}\text { Sweet sorghum } \\
\text { bagasse }\end{array}$ & $\begin{array}{l}\text { Alkaline pretreatment } \\
\text { and enzymatic } \\
\text { hydrolysis }\end{array}$ & - & - & N.D. & N.D. & N.D. & 61.9 & 31.2 & 13.2 & 1.6 & 4.3 & $\begin{array}{c}15.9 \mathrm{di} \\
\text { and/or } \\
\text { oligosugars }\end{array}$ & 17 \\
\hline Miscanthus & $\begin{array}{l}\text { Alkaline and acid } \\
\text { pretreatment and } \\
\text { enzymatic hydrolysis }\end{array}$ & - & - & N.D. & N.D. & - & 38.3 & 26.8 & 10.3 & 1.2 & 3.7 & - & 20 \\
\hline
\end{tabular}

$-:$ information not stated in the paper

N.D.: not detected 
Table 2 Optimal conditions for thermophilic hydrogen and methane production from lignocellulosic hydrolysate.

\begin{tabular}{|c|c|c|c|c|c|c|c|c|c|c|c|c|c|c|c|c|}
\hline \multicolumn{9}{|c|}{ Process Parameter } & \multicolumn{7}{|c|}{ Performance parameters at optimal conditions } & \multirow{3}{*}{ Ref } \\
\hline \multicolumn{2}{|l|}{ Inoculum seed } & \multicolumn{3}{|c|}{ Feedstock } & \multicolumn{2}{|c|}{ Reactor } & \multirow[b]{2}{*}{ Tep } & \multirow[b]{2}{*}{$\mathrm{pH}$} & \multirow{2}{*}{$\begin{array}{l}\text { Conv }{ }^{4)} \\
(\%)\end{array}$} & \multicolumn{3}{|c|}{ Hydrogen production } & \multicolumn{3}{|c|}{ Methane production } & \\
\hline Source & Ino $^{1)}$ & type & $\begin{array}{l}\left.\mathrm{Conc}^{2}\right) \\
\left(\mathrm{g} \mathrm{L}^{-1}\right)\end{array}$ & $\begin{array}{l}\text { OLR } \\
\left(\mathrm{g} \mathrm{L}^{-1} \mathrm{~d}^{-1}\right)\end{array}$ & $\operatorname{Conf}^{3)}$ & HRT & & & & $\begin{array}{c}\text { Yield } \\
\text { ( mmol g }{ }^{-1} \\
\text { sugar) }\end{array}$ & $\begin{array}{c}\text { Rate } \\
\left(\mathrm{mmol}^{1} \mathrm{~d}^{-1}\right) \\
\left.{ }^{-1}\right) \\
\end{array}$ & $\begin{array}{c}\mathrm{Cont}^{5)} \\
(\%)\end{array}$ & $\begin{array}{c}\text { Yield } \\
\left(\mathrm{mmol} \mathrm{g}^{-1}\right. \\
\mathrm{COD})\end{array}$ & $\begin{array}{c}\text { Rate } \\
\left(\mathrm{mmol} \mathrm{L}^{-1} \mathrm{~d}^{-1}\right)\end{array}$ & $\begin{array}{c}\mathrm{Cont}^{5)} \\
(\%)\end{array}$ & \\
\hline Thermoan-aerobacterium & - & $\begin{array}{l}\text { 30\% Cellulose } \\
\text { hydrolysate }\end{array}$ & $7.9^{\mathrm{s}}$ & N/A & Batch & $\mathrm{N} / \mathrm{A}$ & 65 & $\begin{array}{l}5.0- \\
6.0^{\text {ini }}\end{array}$ & 76 & $13.9^{\mathrm{d}}$ & - & - & N.D. & N.D. & N.D. & \multirow{2}{*}{63} \\
\hline Thermoan-aerobacterium & - & $\begin{array}{c}30 \% \text { grass } \\
\text { hydrolysate }\end{array}$ & $7.9^{\mathrm{s}}$ & $\mathrm{N} / \mathrm{A}$ & Batch & N/A & 65 & $\begin{array}{l}5.0- \\
6.0 \\
\text { ini }\end{array}$ & 100 & $8.4^{\mathrm{d}}$ & - & - & N.D. & N.D. & N.D. & \\
\hline $\begin{array}{l}\text { Caldicellulosiruptor } \\
\text { saccharolyticus }\end{array}$ & $10 \%(\mathrm{v} / \mathrm{v})$ & $\begin{array}{l}\text { Sweet sorghum } \\
\text { bagasse } \\
\text { hydrolysate }\end{array}$ & $10.0^{\mathrm{s}}$ & N/A & Batch & $\mathrm{N} / \mathrm{A}$ & 72 & $6.8^{\mathrm{c}}$ & 97 & $14.4^{\mathrm{d}}$ & 244.8 & - & N.D. & N.D. & N.D. & 17 \\
\hline $\begin{array}{l}\text { Thermoanaerobacterium } \\
\text { thermosaccharolyticum }\end{array}$ & $4 \%(v / v)$ & $\begin{array}{l}\text { Corn stover } \\
\text { hydrolysate }\end{array}$ & $11.8^{\mathrm{S}}$ & N/A & Batch & $\mathrm{N} / \mathrm{A}$ & 60 & 7.0 & 100 & $12.4^{\mathrm{d}}$ & 146.8 & - & N.D. & N.D. & N.D. & 19 \\
\hline $\begin{array}{l}\text { Co-culture of } \\
\text { Caldicellulosiruptor sacchar } \\
\text { olyticus and compost } \\
\text { microflora }\end{array}$ & $\begin{array}{c}15 \%(\mathrm{v} / \mathrm{v}) \\
\text { at } 1: 1\end{array}$ & $\begin{array}{c}\text { Synthetic } \\
\text { hydrolysate } \\
\text { with } 1 \%(\mathrm{w} / \mathrm{v}) \\
1: 1 \text { glucose: } \\
\text { xylose } \\
\end{array}$ & $10.0^{\mathrm{s}}$ & N/A & Batch & $\mathrm{N} / \mathrm{A}$ & 70 & $6.5^{\mathrm{c}}$ & 100 & $12.8^{\mathrm{d}}$ & 540 & - & N.D. & N.D. & N.D. & 21 \\
\hline $\begin{array}{l}\text { Co-culture of } \\
\text { Caldicellulosiruptor sacchar } \\
\text { olyticus and } C \text {. } \\
\text { kristjanssoniiat }\end{array}$ & $\begin{array}{c}15 \%(\mathrm{v} / \mathrm{v}) \\
\text { at } 1: 1\end{array}$ & $\begin{array}{c}\text { Synthetic } \\
\text { hydrolysate } \\
\text { with } 1 \%(\mathrm{w} / \mathrm{v}) \\
1: 1 \text { glucose: } \\
\text { xylose } \\
\end{array}$ & $10.0^{\mathrm{S}}$ & N/A & Batch & $\mathrm{N} / \mathrm{A}$ & 70 & $6.5^{\mathrm{c}}$ & 100 & $21.1^{d}$ & 408 & - & N.D. & N.D. & N.D. & \\
\hline $\begin{array}{l}\text { Caldicellulosiruptor } \\
\text { saccharolyticus }\end{array}$ & - & $\begin{array}{l}\text { Miscanthus } \\
\text { hydrolysate }\end{array}$ & $10.0^{\mathrm{s}}$ & N/A & Batch & $\mathrm{N} / \mathrm{A}$ & 70 & - & 100 & $18.9^{d}$ & 302.4 & - & N.D. & N.D. & N.D. & 20 \\
\hline Thermotoga neapolitana & - & $\begin{array}{l}\text { Miscanthus } \\
\text { hydrolysate }\end{array}$ & $14.0^{\mathrm{s}}$ & N/A & Batch & $\mathrm{N} / \mathrm{A}$ & 80 & - & 100 & $17.8^{\mathrm{d}}$ & 295.2 & - & N.D. & N.D. & N.D. & \\
\hline Anaerobic digestion sludge & $0.52 \mathrm{~g} \mathrm{TS} / 1$ & $\begin{array}{l}\text { Groud wheat } \\
\text { hydrolysate }\end{array}$ & $20.0^{\mathrm{s}}$ & N/A & Batch & $\mathrm{N} / \mathrm{A}$ & 55 & $\begin{array}{l}7.0- \\
5.5^{\mathrm{c}}\end{array}$ & 87.5 & $9.9^{\mathrm{d}}$ & 38.2 & - & N.D. & N.D. & N.D. & 64 \\
\hline Anaerobic digestion sluge & $1.5 \mathrm{~g} \mathrm{TS} / 1$ & $\begin{array}{l}\text { Groud wheat } \\
\text { hydrolysate }\end{array}$ & $4.2^{\mathrm{s}}$ & $\mathrm{N} / \mathrm{A}$ & Batch & $\mathrm{N} / \mathrm{A}$ & 55 & $\begin{array}{l}7.0- \\
5.5^{\mathrm{c}}\end{array}$ & 95 & $6.35^{\mathrm{d}}$ & 62.4 & - & N.D. & N.D. & N.D. & \\
\hline Reactor sludge & $20 \%(\mathrm{v} / \mathrm{v})$ & $\begin{array}{l}\text { Wheat straw } \\
5 \% \text { hydrolysate }\end{array}$ & $0.8^{\mathrm{s}}$ & $\mathrm{N} / \mathrm{A}$ & Batch & $\mathrm{N} / \mathrm{A}$ & 70 & - & 97.1 & $13.36^{\mathrm{d}}$ & 7.7 & 17 & N.D. & N.D. & N.D. & 11 \\
\hline
\end{tabular}




\begin{tabular}{|c|c|c|c|c|c|c|c|c|c|c|c|c|c|c|c|c|}
\hline Reactor sludge & $20 \%(\mathrm{v} / \mathrm{v})$ & $\begin{array}{c}\text { Wheat straw } \\
20 \% \\
\text { hydrolysate }\end{array}$ & $3.1^{\mathrm{s}}$ & 1.03 & CSTR & $3 d$ & 70 & $\underset{c}{5.5-5.2}$ & 98 & $8.06^{\mathrm{d}}$ & 8.5 & 37 & N.D. & N.D. & N.D. & \\
\hline Reactor sludge & $42 \%(\mathrm{v} / \mathrm{v})$ & $\begin{array}{c}\text { Wheat straw } \\
20 \% \\
\text { hydrolysate }\end{array}$ & $3.9^{\mathrm{s}}$ & 3.9 & $\mathrm{AF}^{4)}$ & $1 \mathrm{~d}$ & 70 & 5.4 & 94.3 & $5.5^{\mathrm{d}}$ & 20.2 & 32.6 & N.D. & N.D. & N.D. & \multirow{3}{*}{15} \\
\hline Reactor sludge & $45 \%(\mathrm{v} / \mathrm{v})$ & $\begin{array}{c}\text { Wheat straw } \\
20 \% \\
\text { hydrolysate }\end{array}$ & $3.9^{\mathrm{s}}$ & 3.9 & UASB & $1 \mathrm{~d}$ & 70 & 5.1 & 98.1 & $8.8^{\mathrm{d}}$ & 33.6 & 43 & N.D. & N.D. & N.D. & \\
\hline Reactor sludge & - & $\begin{array}{c}\text { Wheat straw } \\
20 \% \\
\text { hydrolysate }\end{array}$ & $3.9^{\mathrm{s}}$ & 1.3 & CSTR & $3 \mathrm{~d}$ & 70 & 5.3 & 97.1 & $7.9^{\mathrm{a} /}$ & 9.9 & 41.5 & N.D. & N.D. & N.D. & \\
\hline $\begin{array}{l}\text { Reactor sludge treating cow } \\
\text { manure }\end{array}$ & $100 \%(\mathrm{v} / \mathrm{v})$ & $\begin{array}{c}\text { Wheat straw } \\
100 \% \\
\text { hydrolysate }\end{array}$ & $38.0^{\mathrm{COD}}$ & 1.9 & CSTR & $20 \mathrm{~d}$ & 55 & 7.4 & 72 & N.D. & N.D. & N.D. & $16.8^{\mathrm{d}}$ & 23.1 & 58.9 & \multirow{3}{*}{12} \\
\hline Thermophilic granule & $39 \%(\mathrm{v} / \mathrm{v})$ & $\begin{array}{c}\text { Wheat straw } \\
10 \% \\
\text { hydrolysate } \\
\end{array}$ & $5.6^{\mathrm{COD}}$ & 2.8 & UASB & $2 \mathrm{~d}$ & 55 & 7.2 & 71 & N.D. & N.D. & N.D. & $15.4^{\mathrm{d}}$ & 30.6 & 66.9 & \\
\hline Thermophilic granule & $39 \%(\mathrm{v} / \mathrm{v})$ & $\begin{array}{c}\text { Co-digestion, } \\
\text { Wheat straw } \\
10 \% \\
\text { hydrolysate and } \\
\text { pig manure (1:3 } \\
\mathrm{v} / \mathrm{v}) \\
\end{array}$ & $17.1^{\mathrm{COD}}$ & 8.53 & UASB & $2 \mathrm{~d}$ & 55 & 7.9 & 71 & N.D. & N.D. & N.D. & $12.6^{\mathrm{d}}$ & 38.2 & 65 & \\
\hline Thermophilic granules & $39 \%(\mathrm{v} / \mathrm{v})$ & $\begin{array}{c}\text { Wheat straw } \\
25 \% \\
\text { hydrolysate }\end{array}$ & $34.2^{\mathrm{COD}}$ & 17.1 & UASB & $48 \mathrm{~h}$ & 55 & $6.8^{\mathrm{c}}$ & 76 & N.D. & N.D. & N.D. & $8.3^{\mathrm{d}}$ & 108.2 & 63.7 & \multirow[t]{2}{*}{10} \\
\hline Thermophilic granules & $75 \%(\mathrm{v} / \mathrm{v})$ & $\begin{array}{l}\text { Wheat straw } \\
\text { hydrolysate }\end{array}$ & $11.3^{\mathrm{COD}}$ & N/A & Batch & $\mathrm{N} / \mathrm{A}$ & 55 & - & - & N.D. & N.D. & N.D. & $\begin{array}{c}13.2 \mathrm{mmol} \\
\mathrm{g}^{-1} \mathrm{VS}^{\mathrm{a}}\end{array}$ & 8.5 & - & \\
\hline
\end{tabular}

1) Ino: inoculation information

ini. $\mathrm{pH}$ was controlled at the beginning of the reaction

2) Conc: substrate loading concentration

c : $\mathrm{pH}$ was controlled at constant value throughout the reaction

3) Conf: configuration of the reactor

a: product yield calculated based on feedstock added

4) Conv: substrate conversion percentage

: product yield calculated based on feedstock digested

5) Cont.: content in the gas phase

-: information not stated in the paper

6) $\mathrm{AF}$ : anaerobic filter reactor

N/A: parameter not applicable due to technological difference

: substrate concentration in unit of g sugar $\mathrm{L}^{-1}$

N.D.: not detected

COD. substrate concentration in unit of 
Table 3 Optimal conditions for thermophilic ethanol and carboxylic acids production from lignocellulosic hydrolysate

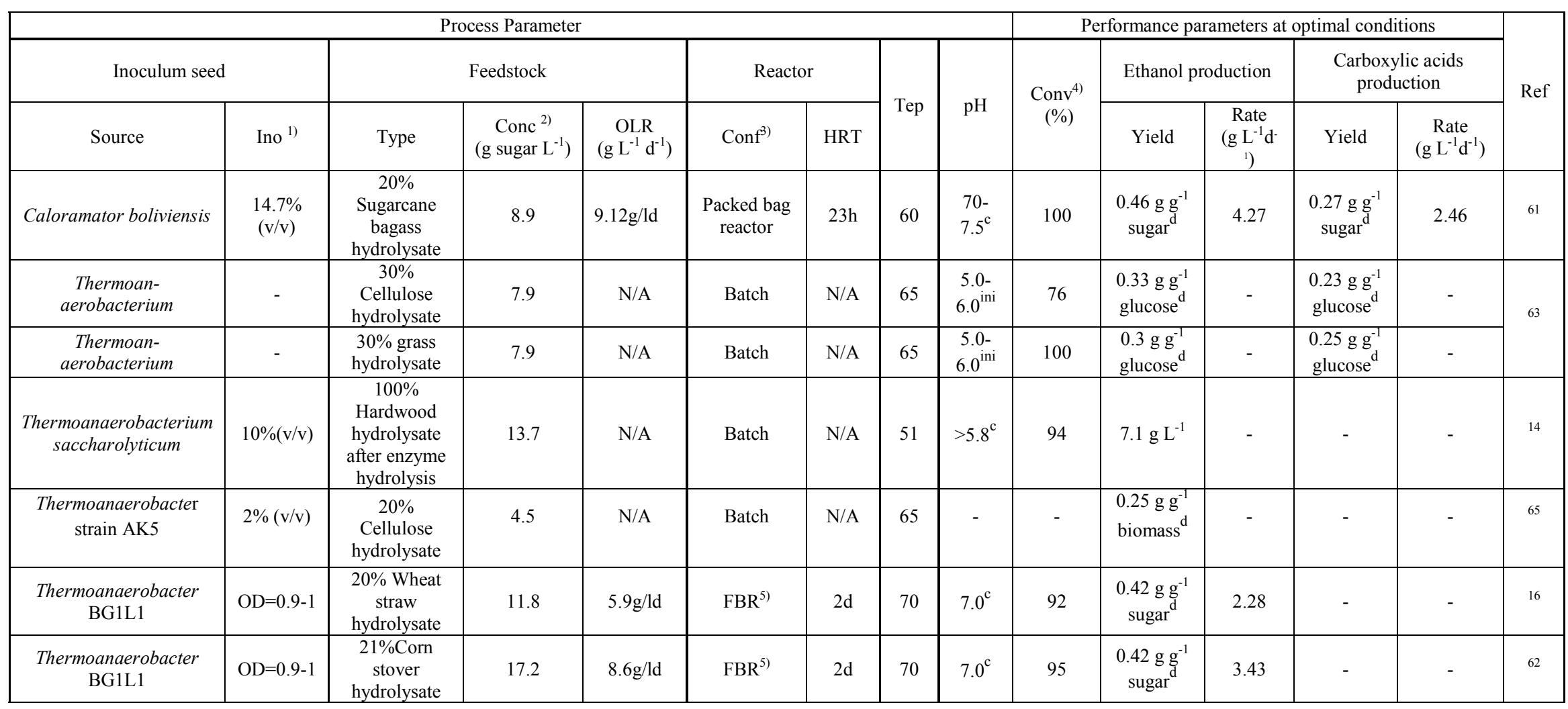

1) Ino: inoculation information

2) Conc: substrate loading concentration

3) Conf: configuration of the reactor

4) Conv: substrate conversion percentage

5) FBR: fluidized bed reactor

ini. $\mathrm{pH}$ was controlled at the beginning of the reaction

c: $\mathrm{pH}$ was controlled at constant value throughout the reaction

a: product yield calculated based on feedstock added

d: product yield calculated based on feedstock digested

$-:$ information not stated in the paper

N/A: information not available due to technological difference

N.D.: not detected 
Table 4 Chemical composition of common lignocellulosic feedstock.

\begin{tabular}{|c|c|c|c|c|c|}
\hline Biomass & Cellulose & Hemicellulose & Lignin & Ash & Reference \\
\hline Rice straw & 41.5 & 19.6 & 22.8 & 10.9 & 30 \\
\hline Wheat straw & $33-40$ & $20-25$ & $12-20$ & - & 66 \\
\hline Barley straw & 37.2 & 24.6 & 16.1 & 6.4 & 13,33 \\
\hline Corn stalk & 36.7 & 26.2 & 16.9 & 4.9 & 13,33 \\
\hline Corn stalk & 36.5 & 31.3 & 11.9 & - & 26 \\
\hline Corn stalk & 31.1 & 27.0 & 14.4 & - & 42 \\
\hline Corn stover & 36.5 & 31.3 & 11.9 & - & 31 \\
\hline Corn stover & 40.3 & 20.8 & 19.1 & - & 19 \\
\hline Corn stover & 37.6 & 21.5 & 19.1 & - & ${ }^{18}$ \\
\hline Hardwood stem & $20-25$ & $45-50$ & $20-25$ & - & 67 \\
\hline Softwood stem & $27-30$ & $35-40$ & $25-35$ & - & 67 \\
\hline Sugarcane baggase & $40-45$ & $30-35$ & $20-30$ & - & 68 \\
\hline Sweet sorghum & 38.5 & 21.4 & 17.6 & 3.7 & 17 \\
\hline bagasse & 42.6 & 27.3 & 21.0 & - & 69 \\
\hline Switchgrass & $31.0-46.2$ & $15.2-22.5$ & 17.8 & - & 70 \\
\hline Switchgrass & $20-28$ & $29-42$ & $3-4 \%$ & - & 70 \\
\hline Napiergrass & 31.5 & 24.5 & 4.2 & - & 71 \\
\hline Napiergrass & $>98$ & - & - & - & 35 \\
\hline Filter paper & & & & & 79 \\
\hline
\end{tabular}

-: information not stated in the paper 
Table 5 Optimal conditions for the thermophilic hydrogen and methane production from lignocellulosic biomass

\begin{tabular}{|c|c|c|c|c|c|c|c|c|c|c|c|c|c|c|c|c|}
\hline \multicolumn{9}{|c|}{ Process Parameters for optimal conditions } & \multicolumn{7}{|c|}{ Performance parameters at optimal conditions } & \multirow{3}{*}{ Ref } \\
\hline \multicolumn{2}{|l|}{ Inoculum seed } & \multicolumn{3}{|c|}{ Feedstock } & \multicolumn{2}{|c|}{ Reactor } & \multirow[b]{2}{*}{ Tep } & \multirow[b]{2}{*}{$\mathrm{pH}$} & \multirow{2}{*}{ Conv $^{4)}$} & \multicolumn{3}{|c|}{ Hydrogen production } & \multicolumn{3}{|c|}{ Methane production } & \\
\hline Source & Ino $^{1)}$ & type & Conc $^{2)}$ & OLR & Conf $^{3)}$ & HRT & & & & Yield & $\begin{array}{l}\text { Rate } \\
(\mathrm{mmol} \\
\left.\mathrm{L}^{-1} \mathrm{~d}^{-1}\right)\end{array}$ & Cont $^{5)}$ & Yield & $\begin{array}{l}\text { Rate } \\
(\mathrm{mmol} \\
\left.\mathrm{L}^{-1} \mathrm{~d}^{-1}\right)\end{array}$ & Cont $^{5)}$ & \\
\hline C. thermocellum ATCC 27405 & $10 \%(\mathrm{v} / \mathrm{v})$ & $\alpha$-cellulose & $1 \mathrm{~g} \mathrm{~L}^{-1}$ & $\mathrm{~N} / \mathrm{A}$ & Batch & N/A & 60 & $7.2^{\mathrm{ini}}$ & $83 \%$ & $\begin{array}{l}\text { 10.6 } \mathrm{mmol} \mathrm{g}^{-1} \\
\text { glucose } \\
\text { equivalent }\end{array}$ & 11.7 & - & N.D. & N.D. & N.D. & 37 \\
\hline C. thermocellum 7072 & $10 \%(\mathrm{v} / \mathrm{v})$ & Corn stalk & $\begin{array}{c}30 \mathrm{~g} \text { TS } \\
\mathrm{L}^{-1} \\
\end{array}$ & N/A & CSTR & N/A & 55 & 7.4 & $63.5 \%$ & $\begin{array}{c}2.5 \mathrm{mmol} \mathrm{g}^{-1} \\
\text { cornstalk }^{\mathrm{d}}\end{array}$ & 23.0 & - & N.D. & N.D. & N.D. & 42 \\
\hline Clostridium sp. TCW1 & - & Filter paper & $5.0 \mathrm{~g} \mathrm{~L}^{-1}$ & $\mathrm{~N} / \mathrm{A}$ & Batch & N/A & 60 & $7.0^{\mathrm{ini}}$ & $99.7 \%$ & $\begin{array}{l}11.3 \mathrm{mmol} \mathrm{g}^{-1} \\
\text { filter paper }\end{array}$ & 56.6 & $36.7 \%$ & N.D. & N.D. & N.D. & 72 \\
\hline $\begin{array}{l}\text { Thermotoga neapolitana DSM } \\
4359\end{array}$ & - & $\begin{array}{l}\text { Pretreated } \\
\text { rice straw }\end{array}$ & $10 \mathrm{~g} \mathrm{~L}^{-1}$ & N/A & Batch & N/A & 75 & $7.5^{\mathrm{ini}}$ & $85.4 \%$ & $\begin{array}{c}2.7 \mathrm{mmol}_{\text {straw }} \\
\text { de-1 }\end{array}$ & 109.8 & $28.1 \%$ & N.D. & N.D. & N.D. & 30 \\
\hline $\begin{array}{c}\text { Caldicellulosiruptor } \\
\text { saccharolyticus. DSM8903 }\end{array}$ & $3 \%(\mathrm{v} / \mathrm{v})$ & Wheat straw & $10 \mathrm{~g} \mathrm{~L}^{-1}$ & N/A & Batch & $\mathrm{N} / \mathrm{A}$ & 70 & $7.2^{\mathrm{ini}}$ & - & $\begin{array}{c}21.1 \mathrm{mmol} \mathrm{g}^{-1} \\
\text { glucose } \\
\text { equivalent }\end{array}$ & - & - & N.D. & N.D. & N.D. & 33 \\
\hline $\begin{array}{c}\text { C. thermocellum DSM } 7072 \\
\text { and C. thermosaccharolyticum } \\
\text { DSM } 869\end{array}$ & $\begin{array}{l}12.5 \% \\
(\mathrm{v} / \mathrm{v}) \text { at } \\
1: 0.25\end{array}$ & $\begin{array}{l}\text { Autoclave } \\
\text { pretreated } \\
\text { cornstalk }\end{array}$ & $10 \mathrm{~g} \mathrm{~L}^{-1}$ & - & CSTR & - & 55 & - & $43.7 \%$ & $\begin{array}{c}3.1 \mathrm{mmol} \mathrm{g}^{-1} \\
\text { cornstalk }^{\mathrm{d}}\end{array}$ & 4.6 & - & N.D. & N.D. & N.D. & 41 \\
\hline $\begin{array}{c}\text { C. thermocellum DSM } 1237 \\
\text { and C.thermopalmarium DSM } \\
1237\end{array}$ & $\begin{array}{l}10 \%(\mathrm{v} / \mathrm{v}) \\
\text { at } 1: 0.05\end{array}$ & Filter paper & $9 \mathrm{~g} \mathrm{~L}^{-1}$ & N/A & Batch & $\mathrm{N} / \mathrm{A}$ & 55 & $6.9^{\mathrm{ini}}$ & $90 \%$ & $\begin{array}{l}7.6 \mathrm{mmol} \mathrm{g}^{-1} \\
\text { glucose } \\
\text { equivalent }\end{array}$ & - & - & N.D. & N.D. & N.D. & 35 \\
\hline Enriched compost & $2 \%(\mathrm{v} / \mathrm{v})$ & Avicell & $5 \mathrm{~g} \mathrm{~L}^{-1}$ & $\mathrm{~N} / \mathrm{A}$ & Batch & N/A & 52 & $7.0^{\mathrm{ini}}$ & $58.3 \%$ & $\begin{array}{l}13.3 \mathrm{mmol} \mathrm{g}^{-1} \\
\text { hexose }^{\mathrm{d}}\end{array}$ & 1.9 & $57 \%$ & N.D. & N.D. & N.D. & 29 \\
\hline Reactor sludge & $25 \%(\mathrm{v} / \mathrm{v})$ & $\begin{array}{c}\text { pretreated } \\
\text { and raw } \\
\text { cornstalk } \\
(1: 5 \mathrm{w} / \mathrm{w})\end{array}$ & $\begin{array}{l}13.3 \mathrm{~g} \\
\text { TS L+ }\end{array}$ & $\mathrm{N} / \mathrm{A}$ & Batch & $\mathrm{N} / \mathrm{A}$ & 55 & - & $41.6 \%$ & $4.8 \mathrm{mmol} \mathrm{g}^{-1} \mathrm{TS}^{\mathrm{d}}$ & 6.3 & -- & N.D. & N.D. & N.D. & 26 \\
\hline $\begin{array}{l}\text { Enriched consortium TC60 } \\
\text { from compost }\end{array}$ & $10 \%(\mathrm{v} / \mathrm{v})$ & $\begin{array}{l}\text { D. tertiolecta } \\
\text { and cellulose } \\
(2: 1 \mathrm{w} / \mathrm{w})\end{array}$ & $\underset{\mathrm{L}^{-1}}{4 \mathrm{~g} \mathrm{VS}}$ & $\mathrm{N} / \mathrm{A}$ & Batch & $\mathrm{N} / \mathrm{A}$ & 60 & $7.0^{\mathrm{ini}}$ & - & $7.7 \mathrm{mmol} \mathrm{g}^{-1} \mathrm{VS}^{\mathrm{a}}$ & 28.2 & - & N.D. & N.D. & N.D. & 34 \\
\hline Marine sediment & - & $\begin{array}{l}\text { Office paper } \\
\text { with chicken } \\
\text { manure }\end{array}$ & $\begin{array}{l}97.5 \mathrm{~g} \\
\text { VS L L }^{-1}\end{array}$ & $\mathrm{~N} / \mathrm{A}$ & Batch & N/A & 55 & $7.0^{\mathrm{ini}}$ & $64 \%$ & $2.2 \mathrm{mmol} \mathrm{g}^{-1} \mathrm{VS}^{\mathrm{d}}$ & 3.2 & - & N.D. & N.D. & N.D. & 38 \\
\hline
\end{tabular}




\begin{tabular}{|c|c|c|c|c|c|c|c|c|c|c|c|c|c|c|c|c|}
\hline Winery & $25 \%(\mathrm{v} / \mathrm{v})$ & $\begin{array}{l}\text { Pretreated } \\
\text { corn stover }\end{array}$ & - & N/A & Batch & $\mathrm{N} / \mathrm{A}$ & 55 & $7.0^{\mathrm{ini}}$ & $37.6 \%$ & $\begin{array}{l}8.5 \mathrm{mmol} \mathrm{g}^{-1} \\
\text { glucose } \\
\text { equivalent }\end{array}$ & - & - & N.D. & N.D. & N.D. & 31 \\
\hline $\begin{array}{l}\text { sludge from municipal } \\
\text { wastewater treatment plant }\end{array}$ & $42 \%(v / v)$ & $\begin{array}{c}\text { Rice straw } \\
\text { size }< \\
0.297 \mathrm{~mm}\end{array}$ & $\underset{\mathrm{L}^{-1}}{90 \mathrm{~g} \mathrm{TS}}$ & N/A & Batch & N/A & 55 & $6.5^{\mathrm{ini}}$ & - & $1.01 \mathrm{mmol} \mathrm{g}^{-1} \mathrm{TS}^{\mathrm{a}}$ & - & - & N.D. & N.D. & N.D. & 36 \\
\hline Cow rumen fluid & $2 \%(\mathrm{v} / \mathrm{v})$ & Avicell & $5 \mathrm{~g} \mathrm{~L}^{-1}$ & N/A & Batch & $\mathrm{N} / \mathrm{A}$ & 60 & $7.3^{\mathrm{ini}}$ & $21 \%$ & $\begin{array}{c}10.7 \mathrm{mmol} \mathrm{g}^{-1} \\
\text { hexose }^{\mathrm{d}}\end{array}$ & 0.28 & - & N.D. & N.D. & N.D. & 28 \\
\hline $\begin{array}{l}\text { Sludge from thermophilic } \\
\text { biogas plant }\end{array}$ & - & $\begin{array}{l}\text { Co-digest } \\
\text { EFB }^{6} \text { with } \\
\text { POME }^{7)}\end{array}$ & $\underset{\mathrm{L}^{-1}}{46 \mathrm{~g} V S}$ & $\mathrm{~N} / \mathrm{A}$ & Batch & N/A & 55 & - & $91 \%$ & ND & ND & ND & $\begin{array}{c}16.0 \\
\mathrm{mmol} \mathrm{g}^{-1} \\
\mathrm{VS}^{\mathrm{a}}\end{array}$ & - & - & 52 \\
\hline Hoggery & $30 \%$ (wt) & $\begin{array}{c}\text { Fungi } \\
\text { pretreated } \\
\text { rice straw }\end{array}$ & $\underset{\mathrm{L}^{-1}}{75 \mathrm{~g} \text { TS }}$ & N/A & Batch & N/A & 55 & - & - & ND & ND & ND & $\begin{array}{c}4.4 \mathrm{mmol} \\
\mathrm{g}^{-1} \mathrm{TS}^{\mathrm{a}}\end{array}$ & 5.7 & - & 73 \\
\hline Reactor sludge & $\begin{array}{l}32.5 \% \\
(\mathrm{v} / \mathrm{v})\end{array}$ & $\begin{array}{c}\text { Slurry } \\
\text { effluent from } \\
\text { ethanol } \\
\text { production }\end{array}$ & - & $\begin{array}{l}3.5 \mathrm{~kg} \\
\mathrm{~m}^{-3} \mathrm{~d}^{-1}\end{array}$ & UASB & $2.1 \mathrm{~h}$ & 53 & $7.8^{\mathrm{c}}$ & $68 \%$ & ND & ND & ND & $\begin{array}{c}13.9 \\
\mathrm{mmol} \mathrm{g}^{-1} \\
\mathrm{VS}^{\mathrm{a}}\end{array}$ & - & - & 54 \\
\hline $\begin{array}{l}\text { C.thermocellum GCD7 and C. } \\
\text { thermosacchara } \\
\text { GSC2Methanoculleus } \\
\text { thermophilicus GML1; } \\
\text { Methanotrix GMK2 and } \\
\text { Methanosarcina thermophila } \\
\text { GMH7 }\end{array}$ & $10 \%(\mathrm{v} / \mathrm{v})$ & $\begin{array}{c}\text { Freeze } \\
\text { explosion } \\
\text { pretreated } \\
\text { stimulated } \\
\text { OFMSW }^{8)}\end{array}$ & $10 \underset{\mathrm{L}^{-1}}{\mathrm{~g} \text { VS }}$ & N/A & Batch & $\mathrm{N} / \mathrm{A}$ & 55 & $9.0^{\mathrm{ini}}$ & - & $4.2 \mathrm{mmol} \mathrm{g}^{-1} \mathrm{VS}^{\mathrm{a}}$ & 68.0 & $55 \%$ & - & - & $<0.1 \%$ & 55 \\
\hline Cow manure & $30 \mathrm{~g} / 1$ & $\begin{array}{l}\text { Effluent from } \\
\text { hydrogen } \\
\text { batch }\end{array}$ & - & $\begin{array}{l}2.6 \mathrm{~g} \\
\text { VFA } \\
\mathrm{L}^{-1} \mathrm{~d}^{-1}\end{array}$ & UASB & $5 \mathrm{~d}$ & 55 & $7.2^{\mathrm{c}}$ & - & - & - & - & $\begin{array}{c}21.2 \\
\mathrm{mmol} \mathrm{g}^{-1} \\
\mathrm{VS}^{\mathrm{a}}\end{array}$ & 11.0 & $78.6 \%$, & \\
\hline $\begin{array}{ll}\text { 1) Ino: inoc } \\
\text { 2) Conc: sul } \\
\text { 3) Conf: cor } \\
\text { 4) Conv: su } \\
\text { 5) Cont.: co } \\
\text { 6) } \\
\text { EFB: oil }\end{array}$ & $\begin{array}{l}\text { ation inform } \\
\text { trate loading } \\
\text { guration of } \\
\text { trate conver } \\
\text { ent in the ga } \\
\text { lm empty fr }\end{array}$ & $\begin{array}{l}\text { tion } \\
\text { concentration } \\
\text { le reactor } \\
\text { on percentage } \\
\text { phase } \\
\text { it bunches }\end{array}$ & & & & & & $\begin{array}{l}\mathrm{a}: \\
\mathrm{d}: \\
-: \\
\mathrm{N} \\
\mathrm{N}\end{array}$ & $\begin{array}{l}\mathrm{pH} \text { was } \\
\mathrm{pH} \text { was } \\
\text { product } \\
\text { product } \\
\text { informa } \\
\text { A: param } \\
\text { D.: not de }\end{array}$ & $\begin{array}{l}\text { ontrolled at the begin } \\
\text { ontrolled at constant } \\
\text { ield calculated based } \\
\text { ield calculated based } \\
\text { on not provided in th } \\
\text { er not applicable due } \\
\text { ected }\end{array}$ & $\begin{array}{l}\text { ng of th } \\
\text { lue thr } \\
\text { feeds } \\
\text { feeds } \\
\text { tudy } \\
\text { techn }\end{array}$ & $\begin{array}{l}\text { action } \\
\text { out the } \\
\text { added } \\
\text { digest } \\
\text { ical dif }\end{array}$ & eaction & & & \\
\hline
\end{tabular}

7) POME: palm

8) OFMSW: organic fraction of municipal solid wastes 
Table 6 Optimal conditions for the thermophilic ethanol and carboxylic acids production from lignocellulosic biomass

\begin{tabular}{|c|c|c|c|c|c|c|c|c|c|c|c|c|c|c|}
\hline \multicolumn{9}{|c|}{ Process Parameter } & \multicolumn{5}{|c|}{ Performance parameters at optimal conditions } & \multirow{3}{*}{ Ref } \\
\hline \multicolumn{2}{|c|}{ Inoculum seed } & \multicolumn{3}{|l|}{ Feedstock } & \multicolumn{2}{|c|}{ Reactor } & \multirow[b]{2}{*}{ Tep } & \multirow[b]{2}{*}{$\mathrm{pH}$} & \multirow{2}{*}{ Conv $v^{4)}$} & \multicolumn{2}{|c|}{ Ethanol production } & \multicolumn{2}{|c|}{$\begin{array}{l}\text { Carboxylic acids } \\
\text { production }\end{array}$} & \\
\hline Source & Ino $^{1)}$ & Type & $\mathrm{Conc}^{2)}$ & $\begin{array}{l}\text { OLR } \\
(\mathrm{g} \mathrm{VS} \\
\left.\mathrm{L}^{-1} \mathrm{~d}^{-1}\right) \\
\end{array}$ & Conf $^{3)}$ & HRT & & & & $\begin{array}{c}\text { Yield } \\
\left(\mathrm{g} / \mathrm{g}^{-1}\right. \\
\text { substrate }) \\
\end{array}$ & $\begin{array}{l}\text { Rate } \\
\left(\mathrm{g} \mathrm{L}^{-1}\right. \\
\left.\mathrm{d}^{-1}\right) \\
\end{array}$ & $\begin{array}{l}\text { Yield } \\
\left(\mathrm{g} \mathrm{g}^{-1}\right. \\
\text { VS) } \\
\end{array}$ & $\begin{array}{l}\text { Rate } \\
\left(\mathrm{g} \mathrm{L} \mathrm{L}^{-1}\right. \\
\left.\mathrm{d}^{-1}\right) \\
\end{array}$ & \\
\hline $\begin{array}{c}\text { Clostridium } \\
\text { thermocellum }\end{array}$ & $\begin{array}{l}1 \% \\
(\mathrm{v} / \mathrm{v})\end{array}$ & Pretreated Napiergrass & $\begin{array}{c}20 \mathrm{~g} \\
\mathrm{~L}^{-1}\end{array}$ & N/A & Batch & N/A & 60 & $7.0^{\mathrm{ini}}$ & $100 \%$ & $0.0476^{\mathrm{d}}$ & - & - & - & 71 \\
\hline C.thermocellum & $\begin{array}{c}1 \% \\
(\mathrm{v} / \mathrm{v})\end{array}$ & Avicel & $\begin{array}{l}10 \mathrm{~g} \\
\mathrm{~L}^{-1}\end{array}$ & N/A & Batch & N/A & 60 & $7.0^{\mathrm{ini}}$ & $100 \%$ & $0.0332^{d}$ & - & - & - & \\
\hline $\begin{array}{l}\text { Co-culture of } C \text {. } \\
\text { themocellum and } C \\
\text { thermolacticum. }\end{array}$ & $\begin{array}{l}10 \% \\
(\mathrm{v} / \mathrm{v}) \\
(1: 1)\end{array}$ & $\begin{array}{l}\text { Microcrystalline cellulose with } \\
\text { ethanol } 4 \mathrm{~g} / 1\end{array}$ & $\begin{array}{l}10 \mathrm{~g} \\
\mathrm{~L}^{-1} 1\end{array}$ & N/A & Batch & N/A & 57 & 9.0 & $99 \%$ & $0.38^{\mathrm{d}}$ & 1.9 & - & - & 43 \\
\hline $\begin{array}{c}\text { Co-culture of } \\
\text { C.thermocellum and } \\
\text { T. Saccharolyticum }\end{array}$ & $\begin{array}{l}20 \% \\
(\mathrm{v} / \mathrm{v}) \\
(1: 1)\end{array}$ & Avicel & $\begin{array}{l}92 \mathrm{~g} \\
\mathrm{~L}^{-1}\end{array}$ & N/A & batch & N/A & 55 & $6.3^{\mathrm{ini}}$ & $90 \%$ & $0.46^{\mathrm{d}}$ & 6.2 & N.D. & N.D.- & 45 \\
\hline $\begin{array}{l}\text { Enriched culture } \\
\text { from compost of } \\
\text { Napiergrass and } \\
\text { sheep dung }\end{array}$ & $\begin{array}{l}1 \% \\
(\mathrm{v} / \mathrm{v})\end{array}$ & Pretreated Napiergrass & $\begin{array}{l}40 \mathrm{~g} \\
\mathrm{~L}^{-1}\end{array}$ & N/A & Batch & $\mathrm{N} / \mathrm{A}$ & 60 & $7.0^{\mathrm{ini}}$ & $100 \%$ & $0.04^{\mathrm{d}}$ & 0.027 & - & - & 71 \\
\hline $\begin{array}{l}\text { Enriched culture } \\
\text { from compost of } \\
\text { Napiergrass and } \\
\text { sheep dung }\end{array}$ & $\begin{array}{l}1 \% \\
(\mathrm{v} / \mathrm{v})\end{array}$ & Avicel & $\begin{array}{l}10 \mathrm{~g} \\
\mathrm{~L}^{-1}\end{array}$ & $\mathrm{~N} / \mathrm{A}$ & Batch & N/A & 60 & $7.0^{\mathrm{ini}}$ & $100 \%$ & $0.108^{\mathrm{d}}$ & 0.013 & - & - & 71 \\
\hline Marine sediment & - & $\begin{array}{l}\text { Lime pretreated water hyacinths } \\
\text { with chicken manure at }(80: 20 \mathrm{wt})\end{array}$ & $\begin{array}{l}100 \mathrm{~g} \\
\mathrm{VS} \mathrm{L}^{-1}\end{array}$ & N/A & batch & N/A & 40 & $7.0^{\mathrm{ini}}$ & $56 \%$ & - & - & $0.53^{\mathrm{d}}$ & 1.1 & 49 \\
\hline $\begin{array}{c}\text { Marine } \\
\text { microorganisms }\end{array}$ & - & $\begin{array}{l}\text { Lime treated bagasse co-digested } \\
\text { with chicken manure }(80: 20 \mathrm{wt})\end{array}$ & $\begin{array}{l}60.6 \mathrm{~g} \\
\mathrm{VS} \mathrm{L}^{-1} \\
\end{array}$ & 2.58 & $\mathrm{SBR}^{5)}$ & $23.5 \mathrm{~d}$ & 55 & 6.6 & $59.5 \%$ & - & - & $0.79^{\mathrm{d}}$ & - & 40 \\
\hline Marine sediment & & $\begin{array}{l}\text { Pretreated sugarcane bagasse and } \\
\text { chicken manure }(80: 20 \mathrm{wt})\end{array}$ & $\begin{array}{l}84.4 \mathrm{~g} \\
\mathrm{VS} \mathrm{L}^{-1}\end{array}$ & 3.26 & MaxAlco & $25.9 \mathrm{~d}$ & 55 & $6.0^{\mathrm{c}}$ & $59 \%$ & - & - & $0.31^{\mathrm{d}}$ & - & 39 \\
\hline
\end{tabular}

1) Ino: inoculation information

2) Conc: substrate loading concentration

3) Conf: configuration of the reactor

4) Conv: substrate conversion percentage

5) SBR: sequential batch reactor

ini: $\mathrm{pH}$ was controlled at the beginning of the reaction c: $\mathrm{pH}$ was controlled at constant value throughout the reaction

: product yield calculated based on feedstock digested

-: information not provided in the study

N/A: parameter not applicable due to technological difference

N.D.: not detected 


\section{Reference:}

1. L. R. Lynd, P. J. Weimer, W. H. Van Zyl, and I. S. Pretorius, Microbiol. Mol. Biol. Rev., 2002, 66, 506-577.

2. S. Raj, S. Talluri, and L. Christopher, BioEnergy Res., 2012, 5, 515-531.

3. S. E. Blumer-Schuette, I. Kataeva, J. Westpheling, M. W. Adams, and R. M. Kelly, Curr. Opin. Biotechnol., 2008, 19, 210-217.

4. M. P. Taylor, K. L. Eley, S. Martin, M. I. Tuffin, S. G. Burton, and D. A. Cowan, Trends Biotechnol., 2009, 27, 398-405.

5. C. Li and H. H. P. Fang, Critical Reviews in Environmental Science and Technology, 2007, 37, $1-39$.

6. N. Ren, A. Wang, G. Cao, J. Xu, and L. Gao, Biotechnol. Adv., 2009, 27, 1051-1060.

7. F. Talebnia, D. Karakashev, and I. Angelidaki, Bioresour. Technol., 2010, 101, 4744-4753.

8. M.-L. Chong, V. Sabaratnam, Y. Shirai, and M. A. Hassan, Int J Hydrogen Energy, 2009, 34, 3277-3287.

9. C.-L. Cheng, Y.-C. Lo, K.-S. Lee, D.-J. Lee, C.-Y. Lin, and J.-S. Chang, Bioresour. Technol., 2011, 102, 8514-23.

10. P. Kaparaju, M. Serrano, and I. Angelidaki, Appl. Energy, 2010, 87, 3779-3783.

11. P. Kongjan, S. O-Thong, M. Kotay, B. Min, and I. Angelidaki, Biotechnol. Bioeng., 2010, 105, 899-908.

12. P. Kaparaju, M. Serrano, and I. Angelidaki, Bioresour. Technol., 2009, 100, 6317-23.

13. I. a Panagiotopoulos, R. R. Bakker, M. A. W. Budde, T. de Vrije, P. A. M. Claassen, and E. G. Koukios, Bioresour. Technol., 2009, 100, 6331-8.

14. J. M. Lee, R. a. Venditti, H. Jameel, and W. R. Kenealy, Biomass Bioenergy, 2011, 35, 626-636.

15. P. Kongjan and I. Angelidaki, Bioresour. Technol., 2010, 101, 7789-7796.

16. T. I. Georgieva, M. J. Mikkelsen, and B. K. Ahring, Appl. Biochem. Biotechnol., 2008, 145, 99 110.

17. I. a. Panagiotopoulos, R. R. Bakker, T. de Vrije, E. G. Koukios, and P. a. M. Claassen, Int J Hydrogen Energy, 2010, 35, 7738-7747.

18. N. Ren, G. Cao, A. Wang, D. J. Lee, W. Guo, and Y. Zhu, Int J Hydrogen Energy, 2008, 33, 6124-6132.

19. G. Cao, N. Ren, A. Wang, D.-J. Lee, W. Guo, B. Liu, Y. Feng, and Q. Zhao, Int J Hydrogen Energy, 2009, 34, 7182-7188.

20. T. De Vrije, R. R. Bakker, M. A. Budde, M. H. Lai, A. E. Mars, and P. A. Claassen, Biotechnol. Biofuels, 2009, 2, 12.

21. A. a. Zeidan and E. W. J. Van Niel, Int J Hydrogen Energy, 2009, 34, 4524-4528.

22. A. L. VanFossen, M. R. A. Verhaart, S. M. W. Kengen, and R. M. Kelly, Appl. Environ. Microbiol., 2009, 75, 7718-7724.

23. S. Kim and B. E. Dale, Biomass Bioenergy, 2004, 26, 361-375.

24. E. M. Rubin, Nature, 2008, 454, 841-845.

25. Koesnandar, N. Nishio, A. Yamamoto, and S. Nagai, J. Ferment. Bioeng., 1991, 72, 11-14.

26. X.-Y. Cheng and C.-Z. Liu, Applied Energy, 2012, 91, 1-6.

27. S. M. Carver, M. C. Nelson, R. Lepistö, Z. Yu, and O. H. Tuovinen, Bioresour. Technol., 2012, 104, 424-31.

28. M. E. Nissilä, H. P. Tähti, J. a. Rintala, and J. a. Puhakka, Int J Hydrogen Energy, 2011, 36, 1482-1490.

29. M. E. Nissilä, H. P. Tähti, J. a Rintala, and J. a Puhakka, Bioresour. Technol., 2011, 102, 4501-6. 
30. T.-A. D. Nguyen, K.-R. Kim, M. S. Kim, and S. J. Sim, Int J Hydrogen Energy, 2010, 35, 13392 13398.

31. C. Liu and X. Cheng, Int J Hydrogen Energy, 2010, 35, 8945-8952.

32. G.-L. Cao, W.-Q. Guo, A.-J. Wang, L. Zhao, C.-J. Xu, Q. Zhao, and N.-Q. Ren, Int J Hydrogen Energy, 2012, 37, 13161-13166.

33. G. Ivanova, G. Rákhely, and K. L. Kovács, Int J Hydrogen Energy, 2009, 34, 3659-3670.

34. S. M. Carver, C. J. Hulatt, D. N. Thomas, and O. H. Tuovinen, Biodegradation, 2010, 22, 805-14.

35. A. Geng, Y. He, C. Qian, X. Yan, and Z. Zhou, Bioresour. Technol., 2010, 101, 4029-33.

36. C.-C. Chen, Y.-S. Chuang, C.-Y. Lin, C.-H. Lay, and B. Sen, Int J Hydrogen Energy, 2012, 1-7.

37. R. Islam, N. Cicek, R. Sparling, and D. Levin, Appl. Microbiol. Biotechnol., 2009, 82, 141-8.

38. A. K. Forrest, M. E. Wales, and M. T. Holtzapple, Bioresour. Technol., 2011, 102, 9823-9826.

39. Z. Fu and M. T. Holtzapple, Appl. Biochem. Biotechnol., 2010, 162, 561-578.

40. Z. Fu and M. T. Holtzapple, Appl. Microbiol. Biotechnol., 2011, 90, 1669-79.

41. Q. Li and C.-Z. Liu, Int J Hydrogen Energy, 2012, 37, 10648-10654.

42. X. Y. Cheng and C. Z. Liu, Energy Fuels, 2011, 1714-1720.

43. L. Xu and U. Tschirner, Bioresour. Technol., 2011, 102, 10065-10071.

44. Q. He, C. L. Hemme, H. Jiang, Z. He, and J. Zhou, Bioresour. Technol., 2011, 102, 9586-9592.

45. D. A. Argyros, S. A. Tripathi, T. F. Barrett, S. R. Rogers, L. F. Feinberg, D. G. Olson, J. M. Foden, B. B. Miller, L. R. Lynd, D. A. Hogsett, and N. C. Caiazza, Appl. Environ. Microbiol., 2011, 77, 8288-8294.

46. S. Yao and M. J. M. J. Mikkelsen, Appl. Microbiol. Biotechnol., 2010, 88, 1-10.

47. Q. He, P. M. Lokken, S. Chen, and J. Zhou, Bioresour. Technol., 2009, 100, 5955-5965.

48. N. K. Budhavaram and Z. Fan, Bioresour. Technol., 2009, 100, 5966-72.

49. A. K. Forrest, J. Hernandez, and M. T. Holtzapple, Bioresour. Technol., 2010, 101, 7510-5.

50. Y.-Q. Tang, P. Ji, J. Hayashi, Y. Koike, X.-L. Wu, and K. Kida, Appl. Microbiol. Biotechnol., 2011, 91, 1447-61.

51. Q. Zhang, J. He, M. Tian, Z. Mao, L. Tang, J. Zhang, and H. Zhang, Bioresour. Technol., 2011, 102, 8899-8906.

52. S. O-Thong, K. Boe, and I. Angelidaki, Appl. Energy, 2012, 93, 648-654.

53. Y. Xia, L. Cai, T. Zhang, and H. H. P. Fang, Int J Hydrogen Energy, 2012, 37, 13652-13659.

54. H. Uellendahl and B. K. Ahring, Biotechnol. Bioeng., 2010, 107, 59-64.

55. G. Kvesitadze, T. Sadunishvili, T. Dudauri, N. Zakariashvili, G. Partskhaladze, V. Ugrekhelidze, G. Tsiklauri, B. Metreveli, and M. Jobava, Energy, 2011, 37, 94-102.

56. X.-Y. Cheng and C.-Z. Liu, Bioresour. Technol., 2012, 104, 373-379.

57. O. M. Pakarinen, H. P. Tähti, and J. a. Rintala, Biomass Bioenergy, 2009, 33, 1419-1427.

58. P. Kongjan, S. O-Thong, and I. Angelidaki, Bioresour. Technol., 2010, 102, 4028-35.

59. P. Kaparaju, M. M. Serrano, A. B. A. B. Thomsen, P. Kongjan, and I. Angelidaki, Bioresour. Technol., 2009, 100, 2562-8.

60. M. O. S. Dias, T. L. Junqueira, O. Cavalett, M. P. Cunha, C. D. F. Jesus, C. E. V. Rossell, R. M. Filho, and A. Bonomi, Bioresour. Technol., 2011, 103, 161-152.

61. C. F. Crespo, M. Badshah, M. T. Alvarez, and B. Mattiasson, Bioresour. Technol., 2012, 103, $186-191$.

62. T. I. Georgieva and B. K. Ahring, Appl. Microbiol. Biotechnol., 2007, 77, 61-8.

63. M. A. Sigurbjornsdottir and J. Orlygsson, Appl. Energy, 2011.

64. S. Ozmihci, F. Kargi, and A. Cakir, Int J Hydrogen Energy, 2011, 36, 2111-2117.

65. H. Brynjarsdottir, B. Wawiernia, and J. Orlygsson, Energy Fuels, 2012, 26, 4568-4574.

66. S. Prasad, A. Singh, and H. C. Joshi, Resources, Conservation and Recycling, 2007, 50, 1-39.

67. P. McKendry, Bioresour. Technol., 2002, 83, 37-46.

68. F. Peng, J.-L. Ren, F. Xu, J. Bian, P. Peng, and R.-C. Sun, J. Agric. Food Chem., 2009, 57, 63056317. 
69. N. K. Pessani, H. K. Atiyeh, M. R. Wilkins, D. D. Bellmer, and I. M. Banat, Bioresour. Technol., 2011, 102, 10618-10624.

70. S.-J. S. J. Yang, I. Kataeva, S. D. S. D. Hamilton-Brehm, N. L. N. L. Engle, T. J. T. J. Tschaplinski, C. Doeppke, M. Davis, J. Westpheling, and M. W. W. M. W. W. Adams, Appl. Environ. Microbiol., 2009, 75, 4762.

71. C.-W. Lin, C.-F. C.-H. Wu, D.-T. Tran, M.-C. Shih, and W.-H. Li, Process Biochem., 2010, 46, 489-493.

72. Y.-C. Lo, C.-Y. Huang, C.-L. Cheng, C.-Y. Lin, and J.-S. Chang, Bioresour. Technol., 2011, 102, 8384-8392.

73. L. Lianhua, L. Dong, S. Yongming, M. Longlong, Y. Zhenhong, and K. Xiaoying, Int J Hydrogen Energy, 2010, 35, 7261-7266. 